\title{
Poezia creştină siriacă în Antichitatea târzie. O scurtă introducere în elementele ei definitorii
}

\author{
Andrei MACAR *
}

\begin{abstract}
Syriac Christian Poetry in Late Antiquity. A brief introduction. The article begins with a chapter on the origin of Syriac poetry, where I point out that it originated in heterodox environments related to Bardesanes in the northern Mesopotamiancityof Edessa. Thereafter I refer to the time of Ephrem the Syrian and the poetic movement he generated by trying to combat heresies. I describe the two forms of his metrical poetry, i.e.memrā and madrāšā, while also refering to the genre called soghīthā, which is in fact a special type of madrāšā. Afterwards I deal with three other smaller Syriac poetic forms and I briefly introduce the most important Syriac poets from Late Antiquity as well
\end{abstract} as some special features of their poetry.

Keywords: Syriac poetry, Bardesanes, memrā, madrāšā, soghīthā, Ephrem the Syriac, Jacob of Serugh, Narsai.

\section{Preliminarii}

Moştenind din lumea iudaică practica adorării lui Dumnezeu prin psalmi şi cântări, creştinii au integrat în cultul liturgic creaţii poetice încă de la începuturile Bisericii. Exemple grăitoare în acest sens sunt cuvintele Apostolului Pavel din Epistola către Coloseni 3:16 ${ }^{1}$, dar şi mărturia proconsulului roman

\footnotetext{
* Doctorand la Facultatea de Teologie a Universităţii Geor-August din Göttingen, Germania.

1 „Cuvântul lui Hristos să locuiască întru voi cu bogăţie. Învăţaţi-vă şi povăţuiţi-vă între voi cu toată înţelepciunea. Cântaţi în inimile voastre lui Dumnezeu, mulţumindu-I în psalmi, în laude şi în cântări duhovniceşti” - Coloseni 3:16.
} 
Plinius cel Tânăr ${ }^{2}$, de la începutul secolului al II-lea. Este bine cunoscut faptul că cele mai vechi cântări religioase ale primilor creştini erau psalmii şi unele texte cu caracter poetic extrase din Vechiul şi Noul Testament ${ }^{3}$. Totuşi, aşa cum aflăm din Coloseni 3:16, creştinii întrebuinţau la adunările lor religioase, alături de aceste imne, şi alte „cântări duhovniceşti”, adică compoziţii poetice originale cu caracter spiritual ${ }^{4}$, fapt confirmat şi de apologetul latin Tertulian $(\dagger \text { cca } 220)^{5}$. Nu avea să treacă mult timp până când aveau să apară chiar şi colecţii întregi de imne creştine originale. Cel mai grăitor exemplu îl constituie opera anonimă Odele lui Solomon, apărută nu mai târziu de anul 125, care foloseşte tehnica poetică a psalmilor. Această colecţie reprezintă cea mai veche carte de imne creştine despre care avem cunoştinţă

${ }^{2}$ „Ei [creştinii, subl. ns.] au susţinut că vinovăţia şi greşeala lor se referă întru totul la faptul că erau obişnuiţi să se adune într-o zi stabilită ca să-I cânte un imn în mod antifonic lui Hristos, ca Dumnezeu..." - Pliny the Younger, Complete Letters, X, 96, translated with an introduction and notes by P.G. Walsh, Oxford, Oxford University Press, 2006, p. 278-279.

3 Cf. Ene Branişte, Liturgică generală, ediţia a III-a, Galaţi, Edit. Episcopiei Dunării de Jos, 2002, p. 315-319.

${ }^{4} \mathrm{Cf}$. Petre VinTILESCU, Despre poezia imnografică din cărţile de ritual şi cântarea

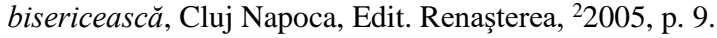

5 „După spălarea mâinilor cu apă şi aprinderea lumânărilor, fiecare este îndemnat să înalţe cântări lui Dumnezeu după puteri, din cărţile sfinte, sau din propria sa minte". Vezi: Tertulian, Apologeticul, XXXIX:18, trad. Eliodor Constantinescu, revăzută de David Popescu, în PSB vol. 3, Bucureşti, Edit. Institutului Biblic şi de Misiune al Bisericii Ortodoxe Române, 1981, p. 94.

${ }^{6}$ Deşi majoritatea Odelor lui Solomon s-au păstrat în limba siriacă, ele nu pot fi încadrate ca aparţinând poeziei creştine siriace întrucât provin dintr-un mediu teologico-cultural diferit (de exemplu forma lor poetică nu corespunde deloc cu cea a poeziei siriace). Odele au fost redactate cel mai probabil de un autor evreu care îl recunoscuse pe Iisus ca Mesia. Cercetările cele mai noi au arătat că acesta era originar din Palestina sau din nord-vestul Siriei, el redactând imnele fie într-o formă timpurie a limbii siro-aramaice, fie chiar în limba greacă. Din punct de vedere formal, aceste imne se aseamănă cu Psalmii lui David, iar conţinutul lor oglindeşte atât idei iudaice şi creştine, cât şi unele elemente proto-gnostice. În plus, autorul lasă să se întrevadă familiaritatea sa cu cercurile eseniene prin similitudinile de limbaj dintre ode şi Regula comunităţii de la Qumran. Odele lui Solomon cunoscute astăzi provin din trei 
Un pas înainte spre dezvoltarea unei poezii creştine variate ca formă de expresie 1-a constituit recursul autorilor la tehnicile imnodice ale lumii elenistice. Astfel, plecând de la modelul imnelor păgâne în proză, apar, încă din secolul al II-lea, omilii poetice ${ }^{7}$. Unul dintre primele exemple îl reprezintă celebrul text Despre Paşti al episcopului Meliton de Sardes († cca 180), care încă mai păstra, totuşi, destule urme ale tehnicilor poetice semitice ${ }^{8}$. Multe dintre imnele creştine compuse până în prima jumătate a secolului al IVlea nu s-au păstrat ${ }^{9}$, dar simbioza realizată între poezia şi proza din lumile semitică şi greacă, precum şi nevoia concretă a Bisericii de a combate diferite grupări eretice care întrebuinţau imnele pe scară largă aveau să determine, de pe la mijlocul secolului al IV-lea, un aflux de texte poetice în spaţiul orthodox ${ }^{10}$. În Răsăritul creştin, această dezvoltare nu a fost apanajul exclusiv al comunităţii vorbitoare de limbă greacă, ci s-a manifestat viguros şi în sânul comunităţii vorbitoare a limbii siriace ${ }^{11}$ din zona nordică a

surse: 40 dintr-un manuscris în limba siriacă, 5 dintr-un manuscris în coptă şi una dintr-un manuscris grecesc (un vers din oda nr. 19, indisponibilă în întregime, este cunoscut printr-o citare în limba latină la scriitorul Lactanţiu). Pentru o introducere şi o traducere în engleză a odelor, vezi: James H. Charlesworth (ed.), The Earliest Christian Hymnbook. The Odes of Solomon, Cambridge, James Clarke \& Co, 2009 (informaţiile introductive leam preluat de la p. XIII-XXIII).

7 Dimitri Conomos, „Hymnography”, in John A. McGuCKIN (ed.), The Encyclopedia of Eastern Orthodox Christianity, vol. I: A-M, Oxford, WileyBlackwell, 2011, p. 321.

${ }^{8}$ John A. McGuckin, „Poetry and Hymnography (2): The Greek World”, in Susan AsHBrooK-HARvey/David G. HunTER (eds.), The Oxford Handbook of Early Christian Studies, Oxford, Oxford University Press, 2008, p. 645.

${ }^{9}$ Câteva scurte cântări creştine vechi, folosite anterior secolului al IV-lea, care s-au păstrat, ar fi formulele doxologice, cântarea Lumină lină, precum şi aclamaţia cunoscută în tradiţia siriacă sub numele lākhū mārā (Ţie Doamne). Vezi: Ene BRANIŞTE, Liturgică generală, p. 319; François CASSINGENA-TRÉVEDY, „L'Hymnographie syriaque”, în François CASSINGENA-TrÉvEDy/Izabela JURASZ (eds.), Les liturgies syriaques, (Études Syriaques 3), Paris, Geuthner, 2006, p. 185.

${ }^{10}$ Dimitri Conomos, „Hymnography”, p. 321-322.

${ }^{11}$ Limba siriacă este o formă a limbii aramaice târzii, provenind din zona oraşului Edessa (astăzi Urfa, în sud-estul Turciei) din nordul Mesopotamiei, fiind 
Mesopotamiei, la graniţa de est a Imperiului Roman. Creştinii de aici au început să folosească atât de mult poezia în viaţa Bisericii, încât nu este greşit să afirmăm că aceasta a devenit pentru tradiţia lor teologică caracteristica principală ${ }^{12}$, ajungând să joace un rol foarte important în întreaga istorie a literaturii siriace.

Datorită caracteristicilor ei unice şi a feluritelor forme de expresie, poezia siriacă a atras atenţia cercetătorilor şi a început să fie tot mai studiată şi tradusă începând cu secolul al XX-lea. În ultimii ani, întâlnim din ce în ce mai des referiri la ea şi în spaţiul teologic românesc, fie că vorbim de contribuţii proprii ale autorilor români ${ }^{13}$, fie de traducerile în limba română ale unor articole şi

atestată din secolul I d. Hr. Aproape toată literatura disponibilă în limba siriacă clasică provinde de la comunităţile creştine care s-au dezvoltat de acolo începând cu secolul al II-lea. „Epoca de aur” a limbii şi literaturii siriace este perioada secolelor IV-VII. După aceea, ea a început să fie înlocuită de creştinii tradiţiei siriace cu limba arabă, cunoscând, totuşi, în secolele XI-XIII o perioadă de renaştere (aşa numita ,renaştere siriacă”). Siriaca clasică încă este folosită astăzi ca limbă liturgică, dar există şi încercări ale unor intelectuali şi savanţi de a reînvia forma clasică ca limbă vorbită (aşa numita ,siriacă kthobonoyo"). Ca limbi vorbite având la bază siriaca clasică, există mai multe dialecte, între care cele mai cunoscute sunt turoyo (în provincia Mardin din sud-estul Turciei) şi sureth (în nordul Irakului, în special în zona Mosul). Vezi: Aaron M. ButTs, „Syriac Language”, în Sebastian Brock et alii (eds), Gorgias Encyclopedic Dictionary of the Syriac Heritage, Piscataway, Gorgias Press, 2011, p. 390-391. Articol disponibil online la adresa https://gedsh.bethmardutho.org/entry/Syriac-Language (accesat la 28.02.2021).

12 Sebastian Brock, reputatul cercetător al creştinismului siriac de la Universitatea din Oxford, preciza că ,,..există un număr important de trăsături care deosebesc tradiţia siriacă locală de alte tradiţii [creştine, subl. ns.]. Probabil că cea mai importantă trăsătură distinctivă este folosirea amplă a poeziei, atât ca vehicul pentru teologie, cât şi pentru învăţământul catehetic" - Sebastian Brock, „Şcolile teologice de la Antiohia, Edessa şi Nisibis”, trad. Andrei Macar, în Teologie şi viaţă, 1-4/2016, p. 160-161.

13 Menţionăm aici doar contribuţiile care au dedicat măcar un capitol poeziei siriace. A se vedea următoarele capitole: Literatura siriană imnografică (p. 270-271), în Ioniţă APOSTOLACHE, „Privire retrospectivă asupra aspectelor hristologice din teologia siriană" în Mitropolia Olteniei, 1-4/2012, p. 252-272; Imnografia, o caracteristică a teologiei siriene (p. 185-187) şi Dimensiunea hristologico-mistică a imnografiei siriene (p. 187-190), în IDEM, „Teologia siriană de la formare la afirmare", în Studia Universitatis Babeş-Bolyai. 
volume ştiinţifice ${ }^{14}$, sau chiar de traducerea unor exemple de poezie siriacă ${ }^{15}$. Recent, chiar şi intelectuali de marcă din România s-au

Theologia Orthodoxa, 1/2014, p. 179-190; Expresia poetică a teologiei syriene (p. 139-140), în Ovidiu PANAITE, „Note introductive pentru o contextualizare istorică şi culturală a creştinismului syriac (II)", în Altarul Reîntregirii, 2/2014, p. 125-144; Mistica legăturii nupţiale în imnografia siriacă (p. 119-122) şi Cântarea Cântărilor, sursă de inspirație în imnografia siriacă (p. 122-124), în Ioniţă APOSTOLACHE, Întunericul luminos. Confluenţe şi idei mistice la Părinţii Orientali. Scrisorile lui Ioan Sabba, misticul sirian din Muntele Dalyatha, Craiova, Edit. Mitropolia Olteniei, 2019, 326 p.

14 A se vedea următoarele capitole din studii sau volume traduse în româneşte: Forma poetică (p. 42-44) şi Poetul ca teolog (p. 48-50), în Sebastian BROCK, Efrem Sirul. I: Ochiul luminos. Viziunea spirituală a lumii la Sfântul Efrem Sirul. II: Imnele despre Paradis, trad. Mircea Ielciu şi Ioan I. Ică jr., Sibiu, Edit. Deisis, 1998, 287 p.; Discursurile in versuri (mimre) şi imnele (madrashe) (p. 265-268), în André de HAlleuX, „Privire critică asupra operei efremiene", anexă în Sebastian BROcK, Efrem Sirul. I: Ochiul luminos..., p. 261-274; Temele poeziei siriace (p. 53-56) şi Categorii de poeţi sirieni (p. 5760), în Ignatius Aphram I BARSOUM, Mărgăritare risipite. $O$ istorie a literaturii şi ştiinţelor siriace, trad. Ovidiu Tămaş, cuvânt înainte de Terezia Filip, Baia Mare, Edit. Proema, 2016, 632 p.

${ }^{15}$ Cele mai cunoscute creaţii poetice siriace disponibile în limba română sunt cele ale Sfântului Efrem Sirul. Ele au fost traduse din limbi moderne (engleză, franceză, germană), iar nu din originalul siriac, având la bază, totuşi, cele mai apreciate traduceri contemporane realizate pe baza originalului. A se vedea următoarele imne: imnele raiului, în Sebastian BROcK, Efrem Sirul. I: Ochiul luminos..., p. 195-260, sau în Sfântul Efrem Sirianul, Imnele raiului, trad. Ioan I. Ică jr., Sibiu, Edit. Deisis, 2010, 152 p.; imnele Naşterii şi Arătării Domnului, în IDEM, Imnele Naşterii şi Arătării Domnului, trad. Ioan I. Ică jr., ediţia a II-a, Sibiu, Edit. Deisis, 2010, 221 p.; imne despre Postul Mare şi Sfintele Paşti, în IDEM, Imnele Păresimilor, Azimelor, Răstignirii şi Învierii, trad. Ioan I. Ică jr., Sibiu, Edit. Deisis, ${ }^{22010,} 253$ p.; imnele perlei I-V, în „Sfântul Efrem Sirul. Imnele Perlei (I și II)”, trad. Ioniţă Apostolache, în Teologie şi viaţă, 1-4/2012, p. 224-236, şi în „Sfântul Efrem Sirul. Imnele Perlei (III-V)", cuvânt introductiv şi trad. Ioniţă Apostolache, în Teologie şi viaţă, 5-8/2013, p. 186-212. În afară de imnele efremiene, mai avem în traducere românească şi alte compoziţii poetice siriace, majoritatea anonime, traduse, de asemenea, după ediţiile moderne. A se vedea: Tânguirea Mariei, nepoata lui Avraam din Qidun (scrisă sub forma unui acrostih în ordine alfabetică), în Sfintele femei ale orientului sirian, texte prezentate şi traduse din limba siriacă de Sebastian P. Brock şi Susan Ashbrook-Harvey, trad. Gheorghe Fedorovici, Bucureşti, Edit. Sophia, 2005, p. 71-76; Heruvimul şi tâlharul 
arătat conştienţi de faptul că tradiţia creştină siriacă a produs „capodopere de poezie liturgică“"16. Prin urmare, merită din plin să zăbovim asupra problematicii poeziei creştine siriace, într-un efort de sincronizare la dezbaterile cercetătorilor occidentali asupra ei,urmărind să-i prezentăm succint originea, reprezentanţii de marcă şi formele în care a fost exprimată, precum şi caracteristicile principale.

\section{Originea poeziei creştine siriace şi primele opere poetice}

Spaţiul geografic şi cultural în care a apărut poezia siriacă este localizat în nordul Mesopotamiei, mai precis în oraşele Edessa $^{17}$ şi Nisibis ${ }^{18}$ cu teritoriile dimprejurul lor. Fiind situate pe Drumul mătăsii, Edessa şi Nisibis erau, în primele secole creştine, punctele principale de atracţie din nordul Mesopotamiei şi locul de întâlnire dintre mari culturi, civilizaţii şi religii ale lumii antice. Substratului aramaic autohton din cele două oraşe i s-au adăugat, de-a lungul timpului, influenţe parto-iraniene (zoroastriene), arabe

(poem dialogic), în Sfântul Efrem Sirianul, Imnele raiului, p. 127-134; Imne dedicate Maicii Domnului, în Mireasa luminii. Imne din Bisericile Siriene despre Maica Domnului, trad. Ioniţă Apostolache şi Hermina Maria Apostolache după versiunea în limba engleză a prof. Sebastian Brock, Craiova, Edit. Mitropolia Olteniei, 2019, 242 p. (volumul cuprinde imne liturgice, poeme dialogice şi omilii în versuri); imn anonim de Bobotează, în Ioniţă Apostolache, Întunericul luminos. Confluenţe..., p. 127-137.

${ }^{16}$ Vezi: Teodor BACONSCHI, „Ucenicii lui Evagrie”, în Dilema veche, nr. 879, 1117 februarie 2021, disponibil la adresa https://dilemaveche.ro/sectiune/dinpolul-plus/articol/ucenicii-lui-evagrie (accesat la 14.02.2021).

17 Astăzi oraşul Urfa, în sud-estul Turciei. Pentru o prezentare introductivă a specificului cultural din Edessa, vezi capitolul Edessa - istorie, cultură, religie (p. 131-140), în Andrei MACAR, „Structuri de învăţământ religios în Edessa. Şcoala perşilor”, în Studii Teologice, 1/2015, p. 129-158.

${ }^{18}$ Astăzi oraşul Nusaybin, în sud-estul Turciei, pe graniţa cu Siria. Pentru o scurtă prezentare, vezi: Hidemi TAKAHASHI, „Nisibis, Nșibin, Nusaybin”, în Sebastian Brock et alii (eds), Gorgias Encyclopedic Dictionary..., p. 310-311. Articol disponibil online la adresa https://gedsh.bethmardutho.org/entry/Nisibis (accesat la 28.02.2021). 
şi, mai ales, elenistice şi iudaice ${ }^{19}$. Comunitatea iudaică din regiune avea o prezenţă multiseculară şi era foarte influentă cultural prin academiile teologice de care dispunea ${ }^{20}$. Limbile principale vorbite aici erau greaca şi acel dialect al aramaicii din care avea să se cristalizeze limba siriacă (numită, de aceea, şisiro-aramaică), o parte semnificativă a locuitorilor fiind bilingvă (în special la Edessa). Peisajul creştin al regiunii, în primele patru secole, nu era unul omogen. La Edessa şi Nisibis coexistau, alături de creştinismul autentic, mai multe grupări de inspiraţie creştină, deloc lipsite de influenţă, care aveau ca figuri centrale nume precum Marcion, Bardesanes sau Mani ${ }^{21}$.

Trebuie spus faptul că sursele disponibile până acum ne arată că poezia siriacă a apărut pentru prima dată tocmai în rândul acestor grupări eretice. Cele două mărturii disponibile în acest sens sunt Istoria bisericească a lui Sozomen († cca 450) $)^{22}$ şi un

${ }^{19}$ Pentru detalii, vezi: Judah B. SEGAL, Edessa: „, The Blessed City”, Oxford, Clarendon Press, 1970, 308 p.; Ute PossEKEL, Evidence of Greek Philosophical Concepts in the Writings of Ephrem the Syrian, (Corpus Scriptorum Christianorum Orientalium 580, Subsidia, 102), Leuven, Peeters, 1999, 265 p. (capitolul Nisibis, Edessa, and the Hellenization of Mesopotamia, p. 13-32); Paul S. Russell, „Nisibis as the background to the life of Ephrem the Syrian", în: Hugoye: Journal of Syriac Studies, 2/2005, p. 179-235; Rocco PALERMO, ,Nisibis, capital of the province of Mesopotamia: some historical and archaeological perspectives", în Journal of Roman Archaeology, 27/2014, p. 456-471.

${ }^{20}$ Despe prezenţa iudaică în nordul Mesopotamiei, vezi: Han J.W. DRIJVERS, ,Jews and Christians at Edessa" in Journal of Jewish Studies, 1/1985, p. 88-102.

${ }^{21}$ Cf. IDEM, Cults and Beliefs at Edessa, Leiden, Brill, 1980, p. 175-196.

22 Sozomen afirmă despre începuturile poeziei siriace următoarele: „eu nu sunt în necunoştinţă de faptul că au existat câţiva bărbaţi foarte învăţaţi şi în Osrhoene [regiunea a cărei capitală era Edessa, subl. ns.], precum Bardesanes, care a întemeiat erezia numită după numele lui, şi Harmonius, fiul său. Se spune că acesta din urmă era foarte elevat în ştiinţa greacă şi a fost primul care a adus sub jugul metrului şi al modurilor muzicale limba lui maternă [adică siriaca, subl. ns.] şi a dat corurilor compoziţiile sale. Chiar şi astăzi sirienii le cântă, adeseori, cântările, folosind, însă, melodiile, iar nu versurile lor. Pentru că Harmonius nu a fost lipsit întru totul de erezia tatălui său, nici de doctrinele filozofilor greci despre suflet, despre originea şi descompunerea corpurilor şi despre reîncarnare... Văzând Efrem că sirienii sunt seduşi de frumuseţea cuvintelor şi a ritmului poeziilor lui Harmonius, iar prin aceasta se obişnuiau să gândească la fel ca el, s-a aplecat asupra înţelegerii metrului folosit de 
imn împotriva ereziilor al Sfântului Efrem Sirul (cca 306-373) ${ }^{23}$. De aici aflăm că primii autori care au compus poezie siriacă au fost Bardesanes (152-222) şi fiul său Harmonius, aceştia organizând chiar coruri care interpretau creaţiile în cadrul adunărilor religioase. Efrem accentuează că Bardesanes a introdus metrul în tehnica poetică şi a încercat să-l imite pe psalmistul David prin frumuseţea poeziei şi prin cele o sută cincizeci de imne pe care le-a compus ${ }^{24}$. Sozomen ne mai arată că Efrem era conştient de atracţia exercitată de aceste imne asupra creştinilor, fiind îngrijorat de faptul că aceştia ajungeau prin ele la învăţături

Harmonius, deşi nu cunoştea cultura greacă, reuşind să compună pe muzica scrierilor lui Harmonius texte conforme cu dogmele Bisericii... De atunci, sirienii cântă melodiile lui Harmonius, dar folosind cuvintele lui Efrem" SozomÈne, Histoire Ecclésiastique, Livre III, 16, 5-7, (Sources Chrétiennes 418), traduction par † André Jean Festugière, revue par Bernard Grillet, Paris, Éditions du Cerf, 1996, p. 150-153. André de Halleux afirmă că atribuirea originii poeziei siriace lui Harmonius este legendară, acest fapt fiind sugerat chiar de numele lui, în timp ce Sebastian Brock consideră informaţia pe care ne-o livrează Sozomen despre ştiinţa greacă a lui Harmonius ca fiind ,produsul şovinismului cultural grecesc”. Prin aceasta, Sozomen ar vrea să scoată în evidenţă că Harmonius a preluat de la greci tehnica poetică. Vezi: André de HALlEUX, „Privire critică asupra operei...”, p. 266; Sebastian BROCK, „Poetry and Hymnography (3): Syriac", în Susan AshBroOK-HARveY/David G. HUNTER (eds.), The Oxford Handbook of Early..., p. 659.

23 „El [Bardesanes, subl. ns.] a compus imne cărora le-a adăugat melodii; / El a compus cântări şi a introdus metrul; / El a divizat frazele prin cadenţă şi măsuri. / Şi a oferit oamenilor sfinţi otravă amară disimulată în dulceaţă. / Bolanvii nu au avut cum să aleagă un remediu folosiror sănătăţii // El a vrut să1 imite pe David şi să se împodobească cu frumuseţea lui. / Năzuind la aceleaşi elogii, el a compus precum David / O sută cincizeci de cântece...” - ÉPHREM DE NISIBE, „Hymne LIII“, în Hymnes contre les hérésies. Hymnes contre Julien, tome II (Sources Chrétiennes 590), texte critique du CSCO - Edmund Beck, introduction, traduction, notes et index Dominique Cerbelaud, Paris, Les Éditions du Cerf, 2017, p. 320-321.

${ }^{24} \mathrm{Cu}$ excepţia unor versuri ale lui Bardesanes citate în unele imne efremiene şi în scrieri ale autorului siro-oriental Theodor bar Koni, nu s-a păstrat nimic din creaţia lui poetică. Vezi: Rubens DuvAL, La littérature syriaque, Paris, Librairie Victor Lecoffre, 1900, p. 18; Han J.W. DRIJVERS, „Solomon as Teacher. Early Syriac Didactic Poetry", in H.J.W. DRIJVERS et alii (eds.), IV Symposium Syriacum 1984. Literary Genres in Syriac Literature (Groningen - Oosterhesselen 10-12 September), (Orientalia Christiana Analecta 229), Roma, 1987, p. 123. 
teologice greşite. Prin urmare, el alege să imite melodiile şi tehnica acestor compoziţii, înlocuind textele cu unele orthodoxe ${ }^{25}$. Relatarea lui Sozomen este confirmată, parţial, de Efrem însuşi, care afirmă într-un imn că a încercat prin opera lui să facă concurenţă ereziilor şi să le combată ${ }^{26}$.

Aceste mărturii textuale ne arată, aşa cum afirmă $F$. Cassingena-Trévedy, că ar fi „,o iluzie să considerăm extraordinara înflorire imnografică din Mesopotamia secolului al IV-lea «miracolul efremian» şi continuarea sa - ca fiind un fel de generaţie spontană. În realitate, Efrem beneficiază, mai mult decât se consideră în general, de o tradiţie literară şi de reprezentări elaborate în medii eterodoxe, el moştenind un instrument deja perfecţionat de predecesori fascinanţi" "27. Acest instrument apăruse într-o cultură retorică şi poetică în care elementele siro-aramaice, de origine semitică, s-au dezvoltat într-un mod aparte în ambianţa nord mesopotamiană impregnată subtil de cultura elenistică. Totuşi, nu este uşor să identificăm influenţele elenistice din poezia siriacă, iar pentru această chestiune cercetătorii nu au găsit încă soluţii definitive ${ }^{28}$. Ele nu trebuie, însă, subestimate, pentru că îşi fac simţită prezenţa în modelele de gândire şi în unele expresii folosite de poeţi ${ }^{29}$.

Pe de altă parte, elementele siro-aramaice locale sunt dominante şi evidente în forma pe care a îmbrăcat-o poezia siriacă. Multe dintre ele înfăţişează semnificative asemănări stilistice şi

${ }^{25} \mathrm{La}$ fel ca în Orient, ereziile au stimulat apariţia poeziei orthodoxe liturgice şi în Occident. Ambrozie de Milan şi Augustin de Hipona au fost impulsionaţi să folosească poezie imnografică în combaterea arienilor şi a donatiştilor care reuşiseră să-i atragă pe mulţi prin creaţiile poetice pe care le întrebuinţau. Cf. François CASSINGENA-TRÉVEDY, „L’Hymnographie syriaque”, p. 192.

26 ,Eu nu am tulburat liniştea turmei tale /Ci, atât cât mi-a fost posibil, / Am dat deoparte lupii din ea. / Şi am construit după puterile mele / Împrejmuirea imnelor, / Pentru oile staulului tău” - ÉPHREM DE NisIBE, „Hymne LVI“, în Hymnes contre les hérésies, p. 365.

${ }^{27}$ François CASSINGENA-TRÉVEDY, „L'Hymnographie syriaque”, p. 191.

${ }^{28}$ Despre influenţele elenistice în opera lui Efrem Sirul şi a poetului Narsai, vezi: Ute PosseKel, Evidence of Greek Philosophical Concepts..., 265 p.; Sebastian BRock, „Greek Words in Ephrem and Narsai: A Comparative Sampling”, în Aram 11-12/1999-2000, p. 439-449.

${ }^{29}$ François CASsingenA-TRÉvedY, „L'Hymnographie syriaque”, p. 186-187. 
tematice chiar cu poezia iudaică din perioada de început a creştinismului. Ele suntdeterminate de înrudirea lingvistică şide schimburile culturale generoase dintre evrei şi creştinii siriaci ${ }^{30}$. Putem aminti, între acestea, câteva asemănări identificate de $\mathrm{O}$. Münz-Manor într-un studiu comparativ al unor creaţii poetice siriace şi iudaice: importanţa acordată metrului silabic,folosirea acrostihului, conţinutul organizat în succesiuni de rânduri a câte patru versuri, dimensiunea narativă a textului, prezenţa dialogului între personajele menţionate şi dezvoltarea conţinutului textului biblic-sursă în cadrul textului poetic ${ }^{31}$.

\section{Formele poetice siriace şi reprezentanţii lor}

Cel care a folosit magistral instrumentul poetic siriac al predecesorilor a fost Sfântul Efrem Sirul ${ }^{32}$. Născut la Nisibis în jurul anului 300, Efrem a activat în cea mai mare parte a vieţiica diacon-imnograf în localitatea natală, fiind ucenic al Sfântului Iacob, episcopul Nisibisului (participant la primul Sinod Ecumenic de la Niceea). În anul 363, a fost nevoit să abandoneze oraşul atunci când romanii 1-au cedat Persiei sasanide, iar ultimii zece ani din viaţă i-a petrecut la Edessa. Creaţia sa poetică siriacă a avut un scop pastoral şi teologic, urmărind să contribuie la statornicirea orthodoxiei în nordul Mesopotamiei. Ea este ancorată

30 Vezi nota 20 şi studiile: Han DrIJVERS, „Syrian Christianity and Judaism”, în Judith LIEU/John NorTh/Tessa RAJAK (eds.), The Jews among Pagans and Christians in the Roman Empire, Londra, Routledge, 1992, p. 124-146; Gerard RouwhORST, „Jewish Liturgical Traditions in Early Syriac Christianity”, în Vigiliae Christianae, 1/1997, p. 72-93.

31 Ophir MünZ-MANOR, „Hebrew and Syriac Liturgical Poetry. A Comparative Outlook", în Aaron M. ButTs/Simcha Gross (eds), Jews and Syriac Christians. Intersections across the First Millennium, (Texts and Studies in Ancient Judaism 180), Tübingen, Mohr Siebeck, 2020, p. 231-253. Analogii între poezia siriacă şi cea iudaică mai menţionează şi R. Duval. Vezi: $L a$ littérature syriaque, p. 16-17.

32 Pentru cercetările teologiei româneşti despre Efrem Sirul, vezi: Varlaam MERTICARIU, Literatura patristică în teologia românească (I). Bibliografie, Bucureşti, Edit. Basilica, 2009, p. 639-660. 
profund în textul şi universul biblic şi recurge, adesea, la imagini şi exemple din lumea înconjurătoare ${ }^{33}$. Nu greşim afirmând că poezia lui a devenit modelul principal la care s-au raportat creaţiile poetice siriace de mai târziu şi doar rareori au reuşit să o depăşească $\breve{~}^{34}$.

Cele două forme poetice făcute celebre de Efrem Sirul se numesc madrāš $\bar{a}$ (pl. madrāše $)^{35}$, adică ,imnul” şi memrā (pl. memre $)^{36}$, adică „discursul” sau „omilia metrică”. Ele sunt diferite sub aspect formal, dar au ca element comun fundamental metrul siriac (syr.mšuhtā). Acesta este diferit de cel al poeziei greceşti care avea la bază cantitatea lungă sau scurtă a silabelor (de exemplu în epopee, tragedie sau în poezia lirică $)^{37}$, fiind bazat pe numărarea silabelor (syr. hegyāne $)^{38}$.In cele ce urmează, vom arăta specificul celor două mari genuri poetice, cu variaţiunile lor, aplecându-ne,

${ }^{33}$ Ute PossEKEL, ,The Emergence of Syriac Literature to AD 400”, in Daniel KING (ed.), The Syriac World, Londra, Routledge, 2019, p. 318-319.

${ }^{34}$ Rubens Duval, La littérature syriaque, p. 19.

${ }^{35}$ Madrāšă înseamnă în siriacă atât ,imn” şi ,,poem în versuri”, cât şi ,comentariu” şi „expunere”. Vezi: J. PAyne-Smith, A Compendious Syriac Dictionary, Oxford, Clarendon Pres, 1903, p. 254. Pentru o explicaţie detaliată a etimologiei, plecând de la rădăcina cuvântului, cu referire şi la alte limbi semitice, vezi: François CASSINGENA-TRÉVEDY, „L'Hymnographie syriaque”, p. 193-194.

36 Termenul memrā nu desemnează în siriacă doar omilia metrică, ci şi un discurs în proză (corespondent al grecescului logos), un tratat, sau chiar un capitol al unei cărţi. Vezi: J. PAYNE-SMith, A Compendious Syriac Dictionary, p. 247; Sebastian BRock, „Later Syriac Poetry”, în Daniel KING (ed.), The Syriac World, p. 334.

37 Petre Vintilescu, Despre poezia imnografică..., p. 14: „În poezia clasică, accentul sau prosodia era metrică sau mai bine zis cantitativă. Îi spunem astfel pentru că indica nu accentul propriu-zis sau tonul, ci durata sau cantitatea silabelor, corespunzătoare cantităţii vocalelor; vocalele lungi şi respectiv silabele lor au în ritmul metric o valoare dublă decât cele scurte. În prosodia metrică, deci, mlădierea vocii la silabele lungi era o chestiune de durată, de intensitate, de timbru".

${ }^{38}$ Pentru o discuție detaliată a metricii siriace, vezi: J.-P. MARTin, De la métrique chez les Syriens, Leipzig, 1879, 71 p.; Gustav HöLsCHER, Syrische Verskunst, Leipzig, 1932, 206 p. 
succint, şi asupra altor trei genuri apărute în Antichitatea târzie, dar care nu au cunoscut o posteritate la fel de grandioasă.

\subsection{Memrā}

Memrā este o compoziţie aparţinând genului epic, fiind formată dintr-o succesiune de versuri-perechi compuse din acelaşi număr de silabe (izosilabice). Cele mai folosite măsuri în memrele siriace sunt cea de şapte silabe, aparţinându-i lui Efrem Sirul (,metrul efremian”), şi cea de douăsprezece silabe (,metrul sarugian”), făcută celebră de autorul miafizit Iacob de Sarug (cca. 451-521), considerat a fi şi maestrul genului memra ${ }^{39}$. Alături de acestea erau folosite, mai rar, măsura de cinci silabe (a lui Balai de Blash - secolele IV-V), măsura de şase silabe şi cea de opt silabe. Cea mai populară măsură a devenit cea a lui Iacob de Sarug, fapt pentru care o bună parte din memrele efremiene au încetat să fie întrebuinţate şi, prin urmare, s-au pierdut. Memrā nu era divizată în strofe, iar uneori putea să aibă dimensiuni foarte întinse ce depăşeau două mii de versuri. Ea era destinată recitării ritmate, fiind compusă mai ales pentru întrebuinţarea liturgică la marile sărbători şi la comemorările sfinţilor. Memrele mai erau folosite în cadrul instrucţiei catehetice a creştinilor, iar uneori şi în spaţiul privat, ca lectură duhovnicească ${ }^{40}$.

În cadrul acestui gen poetic, un loc special îl ocupă memrele narative. Acestea repovestesc evenimente biblice sau biografii ale personajelor biblice şi integrează rostiri ale personajelor. În plus, memrele narative nu conţin aproape deloc intervenţii omiletice ale autorului, dar uneori acesta alege să dezvolte conţinutul textelor biblice prin adăugarea unor episoade fictive ${ }^{41}$. Un exemplu elocvent este reprezentat de două memre din secolul al V-lea despre Avraam şi jertfirea lui Isaac (Facerea 22), atribuite eronat Sfântului Efrem (cel mai probabil anonime) ${ }^{42}$. Contrar descrierii vetero-

${ }^{39}$ Cf. François CASsingenA-TRÉVEDY, „L'Hymnographie syriaque”, p. 204.

${ }^{40}$ Rubens Duval, La littérature syriaque, p. 20-21; Ignatius Aphram I BARsoum, Mărgăritare risipite..., p. 50.

${ }^{41}$ Sebastian BRock, „Poetry and Hymnography (3): Syriac”, p. 663.

42 Pentru textul original siriac, o traducere în engleză şi un comentariu, vezi:

Sebastian Brock, „Two Syriac Verse Homilies on the Binding of Isaac”, în Le 
testamentare, autorul memrelor o introduce în desfăşurarea evenimentelor pe Sara, soţia lui Avraam, şi o transformă în eroina întregului episod. Alte memre narative celebre sunt: memrā despre Iona şi pocăinţa ninivitenilor (autentic efremiană) şi memrā despre Iosif şi fraţii săi (atribuită uneori lui Efrem, alteori lui Balai) ${ }^{43}$. Prima dintre acestea este folosită liturgic în timpul postului ninivitenilor din tradiţia siriacă, dar a devenit cunoscută în întreg spaţiul creştin prin traducerile în greacă, latină, armeană, georgiană şi etiopiană $\left(\mathrm{ge}^{\mathrm{e}} \mathrm{ez}\right)^{44}$.

Un alt grup de memre face parte din categoria poeziei dialogice dramatice, care include atât madrāše (cu varianta soghyāth $\bar{a}$ ) cât şi memre, multe fiind compuse în secolele V-VI. Originea lor trebuie căutată într-un vechi gen de dispute vizavi de prioritatea în rang din literatura antică sumeriană şi acadiană din Mesopotamia. Această categorie prezintă legături evidente cu poezia creştină greacă ulterioară, atât la nivel formal, cât şi în privinţa conţinutului. În plus, cercetătorii au dovedit că ea şi-a manifestat influenţa şi în lumea arabă prin traduceri directe sau adaptări $^{45}$. Compoziţiile din categoria poeziei dialogice dramatice au fost clasificate pentru prima dată de Sebastian Brock, care a identificat cinci tipuri diferite ${ }^{46}$. Unele dintre aceste tipuri sunt prezente fie numai sub formă de memrā, fie numai ca madrāš $\bar{a} / \operatorname{sogh} \bar{t} t h \bar{a}$, fie în ambele forme. Redăm aici tipurile identificate de S. Brock care includ memre dialogice

Muséon, 1-2/1986, p. 61-129 (republicat cu păstrarea paginaţiei din original în cap. VI din IDEM, From Ephrem to Romanos. Interactions between Syriac and Greek in Late Antiquity, Aldershot, Ashgate Variorum, 1999).

${ }^{43}$ IDEM, „Poetry and Hymnography (3): Syriac”, p. 662-663.

${ }^{44}$ Despre variantele siriace şi traducerile acestei memrā, vezi: IDEM, „Ephrem's Verse Homily on Jonah and the Repentance of the Nineveh: Notes on the Textual Tradition", in Peter VANDEuN/Antoon ScHOORS/Carl LAGA (eds), Polihistôr. Miscellanea in Honorem Caroli Laga Septuagenarii, (Orientalia Lovaniensia Analecta 60), Leuven, Peeters, 1994, p. 71-86 (republicat cu păstrarea paginaţiei din original în cap. V din Sebastian BROCK, From Ephrem to Romanos...).

${ }^{45}$ Sebastian Brock, „Dramatic Dialogue Poems”, în H.J.W. DrIJVERs et alii (eds.), IV Symposium Syriacum 1984..., p. 135.

${ }^{46}$ Cf. Ibidem, p. 136-137. 
dramatice (doar patru din totalul de cinci tipuri), urmând ca întrun subcapitol ulterior să ne referim şi la madrāšele din această categorie.

Tipul I cuprinde o singură memrā („,Trupul şi Sufletul II”, atribuită lui Iacob de Sarug $^{47}$ )şi este caracterizat de un dialog realizat sub forma perechilor de versuri care alternează între personaje. Din acest tip lipseşte naraţiunea, cu excepţia unei scurte introduceri. Tipul II este o formă derivată din primul, dar de data aceasta nu mai întâlnim alternanţa câte unei perechi de versuri a fiecăruia dintre cele două personaje, ci alternanţa unor blocuri cu număr neuniform de perechi. Tipul II cuprinde două memre: „Împotriva evreilor” - nr. 6, a lui Iacob de Sarug ${ }^{48}$ şi „Cedrul şi Viţa de vie", a lui David bar Paulos ${ }^{49}$. Tipul IV este format exclusiv din memre, fiind caracterizat de un cadru narativ extins în care sunt purtate dialoguri. Tema abordată în aceste memre este întotdeauna biblică (spre deosebire de celelalte tipuri), dar, având în vedere că autorul spune, de fapt, o poveste, nu sunt prezente

${ }^{47}$ Memra „Trupul şi Sufletul II” este editată de Sebastian Brock în Sogyatha mgabbyatha [Selected Dispute Poems], Glane-Holland, 1982, p. 93-102. Volumul este disponibil online la adresa: https://archive.org/ details/BrockSugyathaMgabyatha/page/n65/mode/2up (accesat la 23.02.2021). O traducere în engleză este disponibilă în Han J.W. DRIJVERS, „Body and Soul: a perennial problem", în G.J. ReININK/H.L.J. VANSTIPHOUT (eds), Dispute Poems and Dialogues in the Ancient and Mediaeval Near East. Forms and Types of Literary Debates in Semitic and Related Literatures, (Orientalia Lovaniensia Analecta 42), Leuven, Peeters/ Departement Oriëntalistiek, 1991, p. 121-134. Pentru textele poetice siriace conţinând dispute între suflet şi trup, vezi: Sebastian BROCK, „Tales of Two Beloved Brothers: Syriac Dialogues between Body and Soul", în Leslie S.B. MaCCoull (ed.), Studies in the Christian East in Memory of Mirrit Boutros Ghali, Washington D.C., 1995, p. 29-38 (republicat cu păstrarea paginaţiei din original în cap. IX din Sebastian BRock, From Ephrem to Romanos...).

${ }^{48}$ Pentru o ediţie a textului siriac împreună cu o traducere în limba franceză, vezi: Micheline AlBERT (ed.), „[Homélie VI] de Mar Jacques, contre les juifs”, în Jaques de Saroug. Homélies contre les juifs, (Patrologia Orientalis 38.1), Turnhout, Brepols, 1976, p. 161-181.

49 O ediţie incompletă oferă P. Y. Dolabani, Egrōthō d-Dōwìd bar Fawlos, Mardin, 1953, p. 166-167, apud Sebastian BROCK, „Dramatic Dialogue Poems", p. 136. 
elemente omiletice. Aici pot fi încadrate şi unele texte poetice din categoria memrelor narative menţionate mai sus: cele două memre despre Avraam şi jertfa lui Isaac şi cea despre Iosif şi fraţii săi. Specifică doar acestei categorii este memrā anonimă „Avraam şi Sara în Egipt" (cf. Facerea 12:10-20), renumită întrucât subiectul este rar abordat în literatura omiletică creştină ${ }^{50}$. Tipul V, ultimul din lista lui S. Brock, cuprinde memrele care introduc elemente omiletice în naraţiunea dramatică. Prin ele, autorul introduce conţinuturi moralizatoare şi exegetice, sau se adresează direct unuia dintre personaje. În acest tip se încadrează, aproape exclusiv, numai memrele, iar cele mai multe dintre ele au fost redactate de Iacob de Sarug şi Narsai (cca 410-503) - memrā „Despre Iosif”.

\subsection{Madrāšāa}

Madrāšă, adică „,imnul”, este o compoziţie a genului liric, fiind alcătuită din versuri dispuse în strofe (syr. baytā) de lungimi diferite. Spre deosebire de memrā, unde întâlnim în general un număr redus de măsuri posibile (mai ales cinci, şapte sau douăsprezece), madrāšele pot folosi un număr foarte variat de măsuri. Totuşi, în întreg cuprinsul unui astfel de imn vom avea întotdeauna acelaşi număr de silabe ${ }^{51}$. Madrāšele Sfântului Efrem şi cele posterioare au fost, fără îndoială, compuse pentru a fi cântate. Nu ştim însă dacă şi cele anterioare, apărute în medii eterodoxe, au fost cântate sau doar recitate ${ }^{52}$. Madrāš ele efremiene erau interpretate fie de un solist, în timp ce un cor cânta refrenul

50 Pentru o ediţie a textului siriac, vezi: Sebastian Brock/Simon HopKINS, „A Verse Homily on Abraham and Sarah in Egypt. Syriac Original with Early Arabic Translation", în Le Muséon, 1-2/1992, p. 87-146.

51 Rubens Duval, La littérature syriaque, p. 22; Sebastian Brock, „Poetry and Hymnography (3): Syriac", p. 658.

52 Pentru o discuţie asupra acestei chestiuni, vezi: Kathleen E. MCVEY, „Were the Earliest Madrāšē Songs or Recitations?", în G.J. REININK/A.C. KLUGKIST (eds), After Bardaisan. Studies on Continuity and Change in Syriac Christianity in Honour of Professor Han J.W. Drijvers, (Orientalia Lovaniensia Analecta 89), Leuven, Peeters/ Departement Oosterse Studies, 1999, p. 185-199. 
(syr. 'ōnith $\left.\bar{a}^{53}\right)$, fie de două coruri, fiecăruia revenindu-i câte un vers. Dacă mărturia lui Iacob de Sarug din memrā despre Sfântul Efrem este adevărată, atunci mai cunoaştem faptul că acestea erau coruri de femei ${ }^{54}$.

Între elementele componente ale unei madrāš $\bar{a}$ mai trebuie amintite cuvintele introductive (syr. $q \bar{a} l \bar{a}^{55}$ ) şi acrostihul. Cuvintele introductive sunt preluate dintr-un imn foarte cunoscut, rolul lor fiind acela de a indica melodia care trebuie folosită la interpretarea vocală a respectivei madrāšā. Numărul acestor melodii este foarte mare, fiind identificate, numai pentru acele madrāše transmise sub numele lui Efrem Sirul, cel puţin şaptezeci şi cinci de melodii ${ }^{56}$. În total, tradiţia poetică siriacă cunoaşte în jur de o sută cincizeci de qāle, dar o bună parte dintre ele nu sunt folosite decât foarte $\operatorname{rar}^{57}$. Celălalt element important al acestui gen, acrostihul ${ }^{58}$, este cunoscut încă din versiunea ebraică a

53 Termenul ōnīthā înseamnă „refren”, „răspuns liturgic”, dar şi „imn” al genului poetic ōnīthā. Vezi: J. PAyne-Smith, A Compendious Syriac Dictionary, p. 405. În tradiţia siro-orientală („,nestoriană”) 'ōnithā a devenit, în secolele IX-XI, chiar un gen poetic folosit liturgic. Acesta este caracterizat de o structură cu trei părţi, dintre care două, prologul şi epilogul, cuprind linii (părţi de vers) de lungimi diferite, în timp ce partea principală este împărţită în versuri care au un număr fix de linii izosilabice. De regulă, un vers conţine patru linii scrise în măsura de şapte silabe. Uneori, apare şi un acrostih alfabetic. Cei mai mari reprezentanţi ai acestui gen au fost Giwargis Warda şi Khamis bar Qardahe. Vezi: Alessandro MengozzI, „'Onithā”, în Sebastian Brock et alii (eds), Gorgias Encyclopedic Dictionary..., p 318. Disponibil online la adresa https://gedsh.bethmardutho.org/Onitha (accesat la 28.02.2021).

${ }^{54}$ Sebastian BROcK, „Poetry and Hymnography (3): Syriac”, p. 659.

${ }^{55}$ Sensul principal al lui $q \bar{a} l \bar{a}$ este „voce”, „sunet”, dar mai înseamnă şi „expresie”, „tonalitate”, ,vers” care indică melodia unei cântări. Prin qālā se mai face referire la şablonul silabic al unei madrāšsa , iar în cadrul liturgic poate desemna un întreg poem în strofe. Vezi: J. PAYne-Smith, A Compendious Syriac Dictionary, p. 505; Sebastian BROCK, „Poetry and Hymnography (3): Syriac”, p. 659.

${ }^{56}$ Ignatius Aphram I BARSOUM, Mărgăritare risipite..., p. 50-51.

${ }^{57}$ Sebastian BROcK, „Later Syriac Poetry”, p. 328.

${ }^{58}$ Despre originea acrostihului pot fi spuse următoarele: „Folosit pentru prima dată de Cicerone şi de Dionisie din Halicarnas, în primele veacuri ale

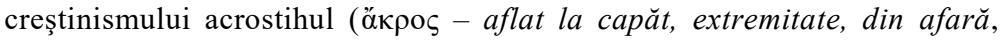

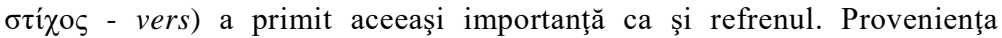


Vechiului Testament (de exemplu din Psalmul 119, Proverbe 31, Plângerile lui Ieremia 1-4), iar în Peshițta, traducerea siriacă a Bibliei, este păstrat doar în Plângerile lui Ieremia ${ }^{59}$. In madrāšele siriace este folosit mai ales acrostihul alfabetic, fiecare strofă având la începutul ei câte una din cele douăzeci şi două de litere ale alfabetului siriac, ceea ce face ca respectiva madrāš $\bar{a}$ să conţină douăzeci şi două de strofe. Un acrostih întâlnit mai rar este cel onomastic (cu numele autorului), prezent încă din compoziţiile efremiene (de exemplu în madrāšele despre Biserică). Deşi depăşeşte cadrul temporal al prezentului studiu, merită amintit aici faptul că, începând cu secolul al IX-lea, poeţii siriaci au introdus rima în structura genului madrāšă. Această evoluţie are de-a face cu dorinţa lor de a imita poezia arabă, întrun context în care creştinismul siriac începea să-şi exprime tot mai des geniul creativ în limba arabă ${ }^{60}$.

acrostihului nu este cunoscută, dar fiindcă cele mai vechi dovezi ale acrostihului se găsesc în rugăciunile babiloniene, se pare că originea răsăriteană nu poate fi exclusă. Există două tipuri de acrostih: cel alfabetic (divizat în acrostihul exterior şi interior) şi cel onomastic. Acrostihul alfabetic a trecut în imnografia creştină prin intermediul modelului ebraic (de exemplu Ps. 118 [sic! corect Ps. 119 din tradiția ebraică a VT, subl. ns.], alcătuit din 22 de secvenţe legate între ele prin literele alfabetului ebraic) şi sirian (imnele efremiene)... Din veacul al IV-lea, acrostihul începe să fie folosit din ce în ce mai mult de imnografii creştini, câştigându-şi definitiv un statut privilegiat în tehnica poeziei imnografice, îndeosebi a acatistului” - Alexandru PreLIPCEAN, „Cuvinte, dă-mi cuvinte”. De la viaţa ,, smeritului Roman” la teologia poetică a Melodului bizantin, Sibiu, Edit. Astra Museum, 2017, p. 144-145.

${ }^{59}$ Ophir MÜNZ-MANOR, „Hebrew and Syriac Liturgical Poetry...”, p. 234, n. 11.

60 Sebastian BROCK, „Poetry and Hymnography (3): Syriac”, p. 658. Sincronizarea la formele poeziei arabe avea să meargă chiar mai departe de atât, iar unii reprezentanţi moderni ai tradiţiei siriace, precum învăţatul patriarh miafizit siro-ortodox Ignatius Aphram I Barsoum (1887-1957), nu au văzut cu ochi buni această dezvoltare. Patriarhul afirma cu indignare că „la finele secolului al treisprezecelea, unii poeţi fanatici au început să imite $\mathrm{cu}$ exagerare instrumentele retorice arabe aşa cum sunt paronomaza şi antiteza. S-au forţat să compună poezie, spoliindu-şi opera prin snobism şi complexitate, prejudiciind echilibrul delicat dintre formă şi conţinut" Ignatius Aphram I BARSOUM, Mărgăritare risipite..., p. 51. 


\subsection{Soghīthā}

O sub-categorie a genului madrāša o reprezintă compoziţiile poetice denumite în siriacă soghyāthā (sg. soghīthā $)^{61}$. Ele au ca trăsătură principală strofa izosilabică compusă din patru versuri a câte şapte silabe. Întrucât aceste compoziţii erau destinate cântării, ele au la început o qāla (melodia), iar strofele sunt separate adesea prin 'ōnithā (refren). De cele mai multe ori este prezent şi acrostihul alfabetic, care nu apare de la prima strofă, ci abia mai târziu, de la momentul începerii dialogului, întrucât primele strofe sunt introductive. Specificul acestui acrostih este faptul că el este dublu, fiecărei litere a alfabetului siriac corespunzându-i câte o replică a celor doi participanţi la dialog. Prezenţa acrostihului alfabetic dublu face ca lungimea imnelor soghïthā să fie de peste patruzeci şi patru de strofe, adăugând şi strofele introductive care variază între două şi douăsprezece strofe ${ }^{62}$. O mare parte a compoziţiilor soghìthā provin din secolele V-VI şi ar putea să îşi aibă originea în contextul cântărilor liturgice, având în vedere că ele sunt transmise aproape exclusiv în manuscrise liturgice ale slujbelor de seară ${ }^{63}$. Majoritatea temelor prelucrate poetic în soghìthā sunt biblice, dar există şi situaţii când tematica compoziţiei este din afara Bibliei, personajele fiind preluate din istoria Bisericii sau reprezentând personificări: împărăteasa Elena şi evreii, Chiril şi Nestorie, trupul şi sufletul, lunile calendarului, grâul şi aurul ${ }^{64}$.

Deşi sunt atestate şi sub alte forme ${ }^{65}$, madrāšele de tipul soghìthā au devenit foarte populare sub forma poeziei dialogice

61 Pentru imne din această categorie traduse în limba română, vezi: Imne dialog (Sogyatha), în Sfântul Efrem Sirianul, Imnele Naşterii şi Arătării..., p. 189218; Heruvimul şi tâlharul, în IDEM, Imnele raiului, p. 127-134; Imne despre Maica Domnului - Soghita 1-3, în Mireasa luminii. Imne..., p. 101-125.

62 Sebastian BROCK, „Syriac Dispute Poems: The Various Types”, în G.J. Reinink/H.L.J. VanstiPhout (eds), Dispute Poems and Dialogues..., p. 110-111.

${ }^{63}$ Sebastian BROCK, „Later Syriac Poetry”, p. 329. Pentru lista manuscriselor care conţin sogyāthā, vezi: IDEM, „Syriac Dispute Poems...”, p. 117-119.

${ }^{64}$ Sebastian BROCK, ,Poetry and Hymnography (3): Syriac”, p. 664.

${ }^{65}$ IDEM, „Syriac Dispute Poems...”, p. 110. 
conţinând sau nu dispute între personaje, menţionată în subcapitolul 3.1.Trei din cele cinci tipuri ale poeziei dialogice dramatice identificate de S. Brock (cf. supra, p. 8) cuprind soghyāthā şi madrāše clasice. Tipul Ile conţine pe amândouă (un exemplu este „Disputa dintre Moarte şi Diavol” a Sfântului Efrem ${ }^{66}$ ), în timp ce în tipul II apar numai primele (de exemplu soghìthā anonimă „Disputa dintre Grâu şi Aur"67). Tipul III, pe care nu 1-am prezentat mai sus întrucât nu includea memre ci exclusiv soghyāthā şi madrāše clasice, este reprezentat de imnele în care dialogul este dominant, dar poate avea mai mult de două personaje. În plus, apare un cadru narativ evident, iar replica unui participant nu mai este restrânsă la o singură strofă care alternează cu replicile celorlalţi, ci participanţilor li se pot acorda replici de dimensiuni diferite. Un exemplu este soghīth $\bar{a}$ despre Avraam şi Isaac $^{68}$, care redă istorisirea din Facerea $22^{69}$.

\subsection{Alte forme poetice întrebuinţate mai rar}

Trei genuri poetice apărute în Antichitatea târzie care au cunoscut o întrebuinţare mai redusă decât memrā, madrāšā şi soghïthāşi sunt folosite în cadrul cultului liturgic se numesc tešbuhtāa, quqoyo şi takšefto. Tešbuhtā (pl. tešbhāta $\bar{a}=$,doxologii“") este o formă poetică cunoscută din tradiţia siro-orientală $\breve{~}^{70}$, fiind compusă din

66 Pentru o traducere în limba germană, vezi: EPHRÄM DER SYRER, Carmina Nisibena, nr. 52 (Bibliothek der Kirchenväter - ediţie electronică), disponibil la adresa https://bkv.unifr.ch/works/193/versions/214/divisions/86585 (accesat la 26.02.2021).

${ }^{67}$ Pentru ediţia textului siriac al acestei sogìthā, vezi: Sebastian Brock, Sogyatha mgabbyatha..., p. 111-112.

68 Textul siriac împreună cu o traducere în limba germană a fost publicat de Bruno Kirschner în articolul său „Alfabetische Akrosticha in der syrischen Kirchenpoesie", în Oriens Christianus. Römische Halbjahrhefte für die Kunde des christlichen Orients, 1-2/1906, p. 44-69. Volumul este disponibil online la adresa https://archive.org/details/orienschristian00grgoog/page/n41/mode/2up (accesat la 26.02.2021).

${ }^{69}$ Sebastian BROCK, „Dramatic Dialogue Poems”, p. 136-137.

70 În cadrul creştinismului siriac există două mari ramuri: cea vestică sau sirooccidentală, reprezentată de Biserica Siro-Ortodoxă sau Iacobită (miafizită), de 
cântări de laudă. Cele mai multe provin din secolele V-VII şi au fost compuse de autori precum Barsauma de Nisibis ( $\dagger$ cca 495), Sabrisho $(†$ 604), Ishoyahb al II-lea († 645), Babai cel Mare $(\dagger 628)$ şi Babai de Nisibis (secolele VI-VII). Majoritatea sunt compuse în perechi de câte patru silabe şi au, uneori, un acrostih alfabetic. $O$ parte dintre aceste tešbhătā au fost preluate şi în tradiţia liturgică maronită ${ }^{71}$.

Celelalte două forme poetice sunt cunoscute din tradiţia sirooccidentală ${ }^{72}$. Quqoyo (pl. quqoye = ,cântări scurte”, „olari”) a apărut în secolele V-VI, iar cel care a compus primele astfel de cântări şi a dat numele acestui gen este Simon Olarul sau Quqoyo (†514). Ele sunt cunoscute dintr-un manuscris siro-occidental copiat în anul 1568 de episcopul Bahnam din Arbo, care i le atribuie eronat pe toate Sfântului Efrem Sirul ${ }^{73}$. In ce priveşte forma poetică takšefto (,rugăminte”, ,implorare”), avem de-a face cu cântări de implorare. S-au transmis până astăzi aproximativ două sute cincizeci, dar nu este clar cine este autorul lor. Unii le atribuie pe toate lui Rabula de Edessa († 435), în timp ce alţii consideră că printre autori se mai numără Efrem Sirul şi Marutha din Takrit $(† 649)^{74}$.

\subsection{Reprezentanţi ai poeziei siriace în Antichitatea târzie}

Creaţia poetică a Sfântului Efrem Sirul a fost imensă. Dacă dăm crezare surselor antice care ne relatează despre ea, aflăm că ar

Biserica Siro-Malankara din India şi de Biserica Maronită, şi ramura estică sau siro-orientală, reprezentată de Biserica Asiriană a Răsăritului (cunoscută adesea ca „Biserica Nestoriană”), de Biserica Caldeeană şi de Biserica SiroMalabar din India. Pentru mai multe informaţii în limba română despre Bisericile Siro-Ortodoxă şi Asiriană, vezi: Martin TAMcke, Creştinii din Tur Abdin. O introducere în istoria Bisericii Ortodoxe Siriace, trad. Dragoş Boicu, Sibiu, Edit. Andreiană, 2015; Wilhelm BAUM/Dietmar W. WINKLER, Biserica Asiriană a Răsăritului. O scurtă introducere în istoria creştinismului sirooriental, trad. Andrei Macar, Iaşi, Edit. Doxologia, 2020.

${ }^{71}$ Sebastian BROCK, „Later Syriac Poetry”, p. 330.

72 Datorită provenienţei lor siro-occidentale, transliterăm vocala lungă ,a” (scrisă în alte situaţii ca ,,ā”) din denumirea celor două forme poetice, sub forma „o”, deoarece ,a"-lung este pronunţat şi tansliterat „," în tradiţia siro-occidentală.

${ }^{73}$ Ignatius Aphram I BARSOUM, Mărgăritare risipite..., p. 117.

${ }^{74}$ Ibidem, p. 117-118. 
fi scris ,aproximativ trei sute de miriade $^{75}$ de versuri”, conform mărturiei lui Sozomen ${ }^{76}$, „un ocean de memre”, după cum afirmă Iacob de $\operatorname{Sarug}^{77}$, şi ,,şase sute optsprezece madrāše”, după o notă din manuscrisul Syr. 10 Sinaiticus ${ }^{78}$. Cele mai vechi manuscrise siriace cu opere efremiene provin de la începutul secolului al VIlea, dar multe dintre textele transmise nu îi aparţin în realitate lui Efrem. De exemplu, faptul că metrul de şapte silabe a devenit cunoscut ca „metrul efremian“ a determinat atribuirea multor memre scrise în acest metru lui Efrem $^{79}$. Cel care a realizat, cu destul succes, restabilirea textelor autentic efremiene a fost benedictinul Edmund Beck (1902-1991), acesta editând critic şi diferenţiat atât textele siriace autentice, cât şi pe cele neautentice, în 38 de volume din colecţia Corpus Scriptorum Christianorum Orientalium $^{80}$. Alături de contribuţia esenţială pe care a adus-o la popularizarea exprimării poetice a teologiei, Efrem a intrat în istorie şi pentru faptul că a fost cel mai important scriitor de madrāšé. Creaţia sa a început să fie tradusă şi în alte limbi, proces început cu limba greacă chiar din timpul vieţii lui. De-a lungul secolelor,au urmat traduceri în armeană, georgiană, coptă, etiopiană, arabă,slavonă şi latină. $\mathrm{O}$ bună parte dintre aceste traduceri au fost

$75 \mathrm{O}$ miriadă cuprinde un număr de zece mii, dar termenul se foloseşte şi pentru a desemna o cantitate foarte mare, nenumărabilă. Numărul indicat de Sozomen este, desigur, ireal.

${ }^{76}$ Sozomène, Histoire Ecclésiastique, Livre III, 16, 4, p. 150-151.

77 Joseph P. AMAR (ed.), A Metrical Homily on Holy Mar Ephrem by Mar Jacob of Sarug, (Patrologia Orientalis 47.1), critical edition of the Syriac text, translation and introduction, Turnhout, Brepols, 1995, p. 32-33.

${ }^{78}$ François CASSINGENA-TRÉVEDY, „L’Hymnographie syriaque”, p. 196.

${ }^{79}$ Sebastian Brock, ,Poetry and Hymnography (3): Syriac”, p. 662.

${ }^{80}$ Ioan I. ICĂ jr., „O teologie poetică a misterului pascal”, studiu introductiv în Sfântul Efrem Sirianul, Imnele Păresimilor, Azimelor..., p. 8. Alături de acest studiu, pentru o introducere în problematica poeziei efremiene a se vedea şi: Ioan I. ICĂ jr., ,Sfântul Efrem, creştinismul siriac şi cealaltă teologie”, studiu introductiv în Sebastian Brock, Efrem Sirul. I: Ochiul luminos..., p. 5-20 şi André de HalleuX, „Privire critică asupra operei efremiene”, anexă în Sebastian BRock, Efrem Sirul. I: Ochiul luminos..., p. 261-274. 
realizate, însă, după „Efremul grec”, fapt pentru care ele nu păstrează mai nimic din formele poetice siriace originare ${ }^{81}$.

Între autorii care au compus poezie siriacă la sfârşitul secolului al IV-lea şi în prima jumătate a secolului al V-lea îi amintim pe Cyrillona, Rabula al Edessei şi Balai de Blash. Despre Cyrillona, informaţiile biografice sunt foarte puţine şi incerte. Se crede că a activat la sfârşitul secolului al IV-lea pentru că menţionează într-un poem o invazie a hunilor ${ }^{82}$. Scrierile lui, exclusiv poetice, au fost descoperite de cercetători la jumătatea secolului al XIX-lea şi sunt transmise într-un singur manuscris păstrat la British Library. Ele au fost considerate încă de la momentul descoperirii ca aparţinând celor mai importante mărturii ale poeziei siriace timpurii ${ }^{83}$. Compoziţiile autentice ale lui Cyrillona sunt în număr de cinci:Despre instituirea Euharistiei, Despre spălarea picioarelor, Despre Paştele Domnului Hristos, Despre calamităţi, Despre Zaheu.

Rabula a fost episcop de Edessa între 411-435, fiind un convertit care a îmbrăţişat creştinismul la vârsta adultă. El stăpânea deopotrivă greaca şi siriaca, a intrat în monahism şi s-a remarcat ca un susţinător înfocat al Sfântului Chiril al Alexandriei în cadrul dezbaterilor hristologice ale epocii (ar fi tradus în siriacă scrieri deale sale). În ce priveşte activitatea scriitoricească, Rabula s-a

81 Pentru o discuţie despre corpusul efremian în limba greacă, vezi: André de HalleuX, „Privire critică asupra operei...”, p. 268-274. Referitor la corpusul de texte greceşti atribuite lui Efrem Sirul merită amintit proiectul dlui asist. dr. Alexandru Prelipcean de a traduce în limba română opera efremiană din corpusul grecesc, după ediţia lui Konstantinos G. Phrantzolas. Vor fi publicate opt volume în colecţia „Patristica. Seria: Traduceri”, de la Editura Doxologia. Până în prezent au ieşit de sub tipar primele trei volume: Sfântul Efrem Sirul, Erminii scripturistice, Iaşi, Edit. Doxologia, 2018; Sfântul Efrem Sirul, Despre cea de-a doua venire a Domnului nostru Iisus Hristos, Iaşi, Edit. Doxologia, 2018; Sfântul Efrem Sirul, Cuvântări de laudă la sfinţi, Iaşi, Edit. Doxologia, 2019.

${ }^{82}$ Carl W. GRIFFIN, Cyrillona: A Critical Study and Commentary, teză de doctorat susţinută la The Catholic University of America, Washington D.C., 2011, p. 43 (teza de doctorat include ediţia textului siriac şi o traducere în engleză, fiind disponibilă online la adresa https://cuislandora.wrlc.org/islandora/object/ etd\%3A125, accesată la 28.02.2021).

${ }^{83}$ Ibidem, p. 2. 
remarcat prin canoanele pentru preoţi, monahi şi bnay qyāmāa (,fiii legământului"), dar şi prin imnele pe care le-a compus ${ }^{84}$. Acestea din urmă sunt cunoscute în tradiţia siro-occidentală cu numele takšefto şi însumează în jur de şase sute de versuri poetice (nu toate îi aparţin cu certitudine lui Rabula). Ele sunt cântări de implorare dedicate marilor praznice, Maicii Domnului, sfinţilor, dar şi celor adormiţi ${ }^{85}$.

Balai de Blasheste foarte cunoscut prin asocierea numelui său cu metrul de cinci silabe. Unii cercetători din secolul trecut au afirmat că el fusese ucenic indirect al Sfântului Efrem Sirul, întrucât ar fi studiat cu un elev al său. Balaişi-a desfăşurat activitatea în zona Alepului, fiind horepiscopul mitropoliei, dar nu deţinem informaţii precise despre viaţa lui. O sursă din secolul al XI-lea susţine că el a devenit episcop de Blash (astăzi localitatea Maskanah din nordul Siriei, la vest de lacul Asad). În anul 432, a scris cinci madrāšse în măsura de cinci silabe prin care îl elogiază pe Acachie al Alepului. A compus numeroase memre în aceeaşi măsură de cinci silabe, care sunt folosite şi astăzi în cult de creştinii siriaci (îndeosebi cele despre pocăinţă şi moarte). Alte memre sunt dedicate sfinţirii unei biserici din Chalcis (în nordul Siriei) şi Sfântului Gheorghe ${ }^{86}$.

În secolul al V-lea, un important reprezentant al poeziei siriace a fost Narsai (cca 410 - 503), numit în tradiţia siro-orientală „harpa Duhului Sfânt” şi „limba Răsăritului”"87. El s-a născut în nordul Mesopotamiei, în teritoriile care făceau parte din Imperiul Sasanid, iar după ce a rămas orfan la vârsta de 16 ani, a fost luat în grijă de unchiul său, stareţul mănăstirii Kfar Mari situată la vest de fluviul Tigru. Narsai a petrecut o perioadă în această mănăstire,

${ }^{84}$ Susan AshbrooK-HARvey, „Rabbula of Edessa”, în Sebastian Brock et alii (eds), Gorgias Encyclopedic Dictionary..., p. 348. Disponibil online la adresa https://gedsh.bethmardutho.org/entry/Rabbula-of-Edessa (accesat la 28.02.2021).

${ }^{85}$ Ignatius Aphram I BARSOUM, Mărgăritare risipite..., p. 263.

${ }^{86}$ Ibidem, p. 264-265.

${ }^{87}$ Aaron Michael ButTs, „Narsai's Life and Work”, în Aaron M. BuTTs/Kristian S. HEAL/Robert A. KITCHEN (eds), Narsai. Rethinking his Work and his World, Tübingen, Mohr Siebeck, 2020, p. 1. 
apoi a plecat să studieze la „Şcoala perşilor” din Edessa ${ }^{88}$. Fiind un student strălucit, a rămas mai departe în cadrul şcolii ca profesor, iar în jurul anului 450 a primit chiar şi funcţia de rabban (director). Această responsabilitate a încetat odată cu expulzarea sa din Edessa, despre care nu avem o dată certă, dar ştim că a avut loc între anii 457 (moartea lui Ibas de Edessa) şi 489 (închiderea „Şcolii perşilor" de către împăratul Zenon). Cel care 1-a primit cu braţele deschise pe Narsai a fost Barsauma, episcopul din Nisibis, localitate la est de Edessa, aflată sub controlul perşilor sasanizi. La îndemnul episcopului, Narsai a înfiinţat la Nisibis o nouă şcoală teologică $\breve{a r}^{89}$ pe care a condus-o până la moartea sa. Prin activitatea lui didactică, această şcoală a preluat preocuparea pentru studiul intens al operei lui Teodor de Mopsuestia († 428), care începuse la şcoala din Edessa cu traducerea în siriacă a scrierilor sale ${ }^{90}$.

Opera poetică a lui Narsai este foarte extinsă. Autorul sirooriental Abdisho bar Brikha († 1318) afirmă că Narsai a scris 360 de memre, împărţite în douăsprezece volume. Dintre toate aceste memre mai sunt cunoscute numai în jur de 80 , iarcel mai vechi manuscris al memrelor disponibil provine din secolele XII-XIII ${ }^{91}$.

88 Despre activitatea „Şcolii perşilor” din Edessa şi închiderea ei, vezi studiul nostru „Structuri de învăţământ religios în Edessa. Şcoala perşilor”, în Studii Teologice, 1/2015, p. 129-158.

89 Despre această şcoală teologică, vezi: Ute PossEKEL, „Selbstverständnis und Bildungsauftrag der Schule von Nisibis“, în Zeitschrift für Antikes Christentum, 1/2015, p. 104-136; Sebastian BROCK, ,Şcolile teologice de la Antiohia, Edessa şi Nisibis", trad. Andrei Macar, în Teologie şi viaţă, 1 4/2016, p. 149-168.

90 Lucas Van RoMPAY, „Narsai”, în Sebastian BROCK et alii (eds), Gorgias Encyclopedic Dictionary..., p. 303. Disponibil online la adresa https://gedsh.bethmardutho.org/entry/Narsai (accesat la 28.02.2021).

91 Până acum au existat mai multe ediţii şi traduceri ale unora dintre memrele lui Narsai, dar nu toate corespundeau exigenţelor criticii textuale. Prin urmare, cu câţiva ani în urmă, a fost iniţiat un proiect de editare critică şi de traducere în limba engleză a tuturor memrelor disponibile scrise de Narsai, coordonat de Aaron M. Butts, Kristian S. Heal şi Robert A. Kitchen. În cadrul acestui proiect a apărut până acum volumul: Aaron M. BuTTS/Kristian S. HeAL/Sebastian Brock, Clavis to the Metrical Homilies of Narsai, (Corpus Scriptorum Christianorum Orientalium 690, Subsidia 142), Leuven, Peeters, 2021, 166 p. (prima parte include o enumerare a memrelor alături de manuscrisele în care 
În privinţa formei folosite, cele mai multe memre au fost scrise în măsura de douăsprezece silabe, iar câteva în măsura de şapte silabe. Narsai a dedicat conţinutul lor în special exegezei biblice, temelor teologice, liturgice şi morale ${ }^{92}$. Una dintre memre este o apărare a unor dascăli ai teologiei antiohiene, şi anume Diodor de Tars, Teodor de Mopsuestia şi Nestorie. Este cunoscut faptul că Narsai sa intersectat pentru un timp la Edessa cu un alt mare compozitor de poezie siriacă, în persoana lui Iacob de Sarug (cca 451 - 521). Dacă pe cei doi îi unea interesul pentru poezie, opţiunile teologice îi despărţeau. Primul a ales să ducă mai departe,prin poezie, moştenirea teologică şi exegetică a antiohienilor şi a lui Teodor de Mopsuestia, în timp ce al doilea, deşi 1-a folosit discret pe Teodor în memrele sale, a ales să rămână mai apropiat de Efrem Sirul şi Chiril al Alexandriei ${ }^{93}$.

Iacob de Sarug este unul dintre cei mai cunoscuţi autori din tradiţia siro-occidentală, unde este numit „flautul Sfântului Duh” şi „harpa Bisericii”. Născut la Kurtam, localitate pe malul fluviului Eufrat, Iacob a primit educaţia teologică la „Şcoala perşilor" din Edessa. După aceea, a fost horepiscop de Hawra, iar la vârsta de 67 de ani ajunge episcop de Batnan da-Srug ${ }^{94}$. Aşa cum am amintit deja, Iacob este maestrul genului memrā, folosind măsura de douăsprezece silabe (metrul sarugian). Tradiţia menţionează că ar fi scris 763 de memre, dar până la noi s-au transmis sub numele lui

sunt disponibile, de ediţiile precedente şi de traduceri şi studii realizate până acum. Partea a II-a este un studiu al manuscriselor, iar partea a III-a este o concordanţă. Dintre ediţiile şi traducerile mai vechi, vezi: Frederik G. MCLEOD (ed.), Narsai's Metrical Homilies on the Nativity, Epiphany, Passion, Ressurection and Ascension, (Patrologia Orientalis 40.1), critical edition of Syriac text and English translation, Turnhout, Brepols, 1979; Judith FRISHMAN, The Ways and Means of the Divine Economy. An Edition, Translation and Study of Six Biblical Homilies by Narsai, Leiden, Rijksuniversiteit, 1992 (teză de doctorat).

92 Aaron Michael BuTts, „Narsai's Life and Work”, p. 6-8.

${ }^{93}$ Lucas Van RoMPAY, „Narsai”, p. 303-304.

${ }^{94}$ Pentru mai multe informaţii biografice despre Iacob de Sarug în limba română, vezi: Ioniţă APOSTOLACHE, „Specificul apologetic al teologiei lui Iacob de Sarug în contextul teologiei siriene", în Revista Teologică, 4/2015, p. 56-57; Ignatius Aphram I BARSOUM, Mărgăritare risipite..., p. 276-283. 
numai 380 (nu toate îi aparţin cu certitudine), cele mai vechi manuscrise disponibile fiind chiar din secolul al VI-lea ${ }^{95}$.

Lăudând creaţia poetică a lui Iacob de Sarug, patriarhul siroortodox Ignatius Barsoum (1887-1957) spunea că ea include „capodopere şi frumuseţi care uimesc raţiunea şi copleşesc inima. Ele se caracterizează de asemenea, prin stilul lor imaculat şi prin precizie, prin subiectele atractive, exprimarea meşteşugită, prin fermitatea şi limpezimea formei" 96 . Patriarhul îi îndeamnă stăruitor pe creştini să folosească scrierile lui Iacob în viaţa duhovnicească: „citiţi memrele sale care îndeamnă la lepădarea plăcerilor lumeşti şi pocăinţă; veţi constata că înainte de a fi ajuns la final, inima voastră a renunţat deja la lucrurile pământeşti, umplându-se de iubire, credinţă şi sfinţenie. Indiferent cât de departe eşti de starea de dreptate, memrele sale îţi vor sensibiliza sufletul ca să baţi la uşa lui Dumnezeu, să intri şi să locuieşti împreună cu El"97. Memrele lui Iacob cuprind multe comentarii scripturistice, dar abordează şi teme precum învierea, credinţa, rugăciunea, pocăinţa, virtuţile creştine, mariologia, apostolii şi martirii. Ele sunt cântate zilnic în cultul Bisericii Siro-Ortodoxe ${ }^{98}$. Alte memre sunt dedicate unor sfinţi, cum e cea despre Simeon Stâlpnicul, dar există şi şase memre polemice împotriva evreilor, între care una este scrisă sub forma dialogului dintre un creştin şi un evreu. În afară de memre, lui Iacob de Sarug îi mai sunt atribuite în manuscrise atâtmadrāše, cât şi soghyāthā, dar numărul lor este mult mai redus ${ }^{99}$.

Contemporan cu Iacob de Sarug a fost poetul Simon Olarul ( 514$)$, despre care nu avem informaţii biografice foarte precise.

95 Sebastian Brock, „Ya qub of Serugh”, în Sebastian Brock et alii (eds), Gorgias Encyclopedic Dictionary..., p. 433-434. Disponibil online la adresa https://gedsh.bethmardutho.org/entry/Yaqub-of-Serugh (accesat la 28.02.2021). Întreaga poezie metrică a lui Iacob de Sarug este în proces de editare şi traducere la editura Gorgias Press (Piscataway, New Jersey), în colecţia „Texts From Christian Late Antiquity”, mai multe volume fiind deja publicate.

${ }^{96}$ Ignatius Aphram I BARSOUM, Mărgăritare risipite..., p. 276-277.

${ }^{97}$ Ibidem, p. 277.

${ }^{98}$ Ibidem, p. 278-279.

${ }^{99}$ Sebastian BROCK, „Later Syriac Poetry”, p. 329. 
Ştim că s-a născut în zona Antiohiei şi se ocupa cu fabricarea vaselor de lut. Tradiţia ne spune că el a început să compună poezii lipsite de complexitate în timp ce lucra la roata lui, pe care mai apoi le cânta folosind melodii renumite. Acestea au ajuns să formeze un nou gen poetic cunoscut sub denumirea quqoyo, care a pătruns în grupul select al cântărilor liturgice din Biserica Siro-Ortodoxă. Între subiectele abordate de compoziţiile lui Simon Olarul amintim Naşterea Domnului, Învierea şi minunile lui Iisus, Maica Domnului $^{100}$, profeţii şi sfinţii ${ }^{101}$. Simon ar fi fost lăudat pentru poezia sa chiar de Iacob de Sarug, care 1-ar fi vizitat la atelierul său în anul $510^{102}$.

Din perioada secolelor V-VI mai există aproape două sute de memre în perechi de versuri a câte şapte silabe,transmise într-un singur corpus sub numele lui Isaac de Antiohia ${ }^{103}$. În acest caz, nu avem însă de-a face cu un singur autor, fapt cunoscut încă din timpul episcopului Iacob de Edessa (cca 630-708), ci cu trei, despre care nu sunt cunoscute prea multe informaţii biografice: Isaac al Amidei, Isaac Antiohianul şi Isaac din Edessa ${ }^{104}$. Isaac al Amidei ar fi fost elev al lui Zenovie, ucenic al lui Efrem Sirul, şi ar fi vizitat Roma şi Constantinopolul în timpul împăratului Arcadie (395-408). El ar fi scris o memrā despre jocurile seculare din Roma şi una despre căderea Romei în anul 410 sub vizigoţii lui Alaric, dar niciuna dintre

100 Imnele lui Simon Olarul despre Maica Domnului au fost traduse şi în limba română de Ioniţă Apostolache şi Hermina M. Apostolache după traducerea în limba engleză a lui Sebastian Brock. Vezi: Mireasa luminii. Imne..., p. 146-155.

101 Pentru nouă imne ale lui Simon editate şi traduse în limba germană, vezi: Sebastian EURINGER, „Die neun «Töpferlieder» des Simeon von Gêšîr”, în Oriens Christianus. Halbjahrshefte für die Kunde des christlichen Orients, neue Serie, 3/1913, p. 221-235. Volumul este disponibil online la adresa https://archive.org/details/in.ernet.dli.2015.56167/mode/2up (accesat la 28.02.2021).

102 Ignatius Aphram I BARSOUM, Mărgăritare risipite..., p. 273-274.

103 Doar o parte dintre ele au fost publicate, în timp ce multe sunt încă în manuscris. Vezi: Paul BedJAN (ed.), Homiliae S. Isaaci Syri Antiocheni, Paris/Leipzig, Harrassowitz, 1903, 860 p. Volum disponibil online la adresa https://archive.org/details/homiliaesisaacis01isaauoft (accesat la 28.02.2021).

${ }^{104}$ Sebastian BROCK, „Later Syriac Poetry”, p. 328. 
aceste memre nu s-a păstrat ${ }^{105}$. Isaac Antiohianul a fost un preot renumit din Edessa, activând în timpul împăratului roman Zenon. El a călătorit la Antiohia în timpul patriarhului Petru Gnafes (470-471 şi 485-489) şi a fost implicat în controversa privitoare la cântarea Trisaghion. La Antiohia, Isaac ar fi văzut un om care mergea ţinând un papagal învăţat să cânte Trisaghionul, ceea ce 1-a determinat să scrie o memrā despre cele petrecute. Această compoziţie poetică a circulat sub numele „Isaac Antiohianul” pentru că autorul ei se afla la Antiohia atunci când a redactat-o ${ }^{106}$. Despre ultimul din cei trei poeţi cu numele Isaac cunoaştem şi mai puţine lucruri. El ar fi fost preot la Edessa în prima parte a secolului al VI-lea, iar în timpul disputei teologice din oraş a fost, iniţial, susţinător al grupării miafizite. După un timp, Isaac a renunţat la convingerile mai vechi şi a devenit susţinătorul teologiei calcedoniene, redactând mai multe memre în favoarea acesteia ${ }^{107}$.

\section{Epilog: caracteristicile şi importanţa poeziei siriace}

Una dintre cele mai importante caracteristici ale poeziei siriace din Antichitatea târzie este exprimarea teologiei prin poezie. În acest demers, poeţii siriaci au folosit din plin, alături de textul biblic, bogăţia simbolurilor, a metaforelor şi a imaginilor. Astfel, a luat naştere o nouă formă de exprimare a adevărurilor de credinţă, diferită de cea din lumea greco-latină care era impregnată de conceptualismul filozofiei greceşti. Cele două forme de teologhisire pot fi complementare, dar spre deosebire de teologia greacă,

${ }^{105}$ Edward G. Mathews jr., „Ishaq of Amid”, în Sebastian Brock et alii (eds), Gorgias Encyclopedic Dictionary..., p. 212. Disponibil online la adresa https://gedsh.bethmardutho.org/entry/Ishaq-of-Amid (accesat la 28.02.2021).

${ }^{106}$ Edward G. MATHEws jr., „Isḥaq of Antioch”, în Sebastian BROCK et alii (eds), Gorgias Encyclopedic Dictionary..., p. 213. Disponibil online la adresa https://gedsh.bethmardutho.org/entry/Ishaq-of-Antioch (accesat la 28.02.2021); Ignatius Aphram I BARSOUM, Mărgăritare risipite..., p. 267.

${ }^{107}$ Edward G. MATHEws jr., „Ishaq of Edessa”, în Sebastian BROCK et alii (eds), Gorgias Encyclopedic Dictionary..., p. 213. Disponibil online la adresa https://gedsh.bethmardutho.org/entry/Ishaq-of-Edessa (accesat la 28.02.2021). 
teologia poetică siriacă are avantajul că nu caută definiţii clare şi răspunsuri unice, ci încearcă să evidenţieze şi să preamărească tainele creştinismului, având la dispoziţie instrumentul poetic care permite răspunsuri multiple, favorizând pluralitatea ${ }^{108}$.

Poezia siriacă se mai distinge prin caracterul ei descriptiv, atât în compoziţiile care explică textul scripturistic, cât şi în cele care au ca în vedere temele teologice. În plus, ea înfăţişează o dimensiune ascetico-penitenţială, îndemnând, adesea, renunţarea la bunurile acestei lumi şi orientarea vieţii spre pocăinţă şi căutarea mântuirii. Uneori poezia siriacă a luat forma elegiei, anumite creaţii poetice exprimând părerea de rău pentru păcatele săvârşite sau lamentaţii ale creştinilor din timpul prigonirilor sau al calamităţilor naturale. De asemenea, există poezii care deplâng durerea interioară produsă de pierderea unor personalităţi şi chiar a cărţilor siriace (poeme mai târzii, posterioare secolului al XIII-lea). Pe de altă parte, am văzut că poezia siriacă a secolului al IV-lea a mai fost folosită şi ca instrument de critică şi de protest împotriva ereticilor, creştinii fiind avertizaţi să se îndepărteze de învăţăturile unora ca Bardesanes, Marcion sau Mari şi să adere la credinţa dreaptă. Ea foloseşte lauda pentru a-L slăvi pe Dumnezeu şi a cinsti Biserica $\mathrm{Sa}$, precum şi pentru a identifica modelele pe care creştinii trebuie să le urmeze în viaţa lor: profeţii,apostolii, Maica Domnului, sfinţii, martirii şi personalităţile teologice. Deşi în poezia siriacă a Antichităţii târzii nu şi-au făcut loc ideile filozofilor greci, acestea aveau să apară, mai târziu, la autori din timpul renaşterii siriace (secolele XI-XIII). Au fost preluate mai ales cele despre valoarea sufletului şi modul de perfecţionare a lui şi îndemnurile la atitudini morale durabile (în poeziile lui Bar Ma dani şi Bar Hebraeus) ${ }^{109}$.

S. Brock consideră că poezia siriacă mai este caracterizată de prospeţime, stil direct, bogăţie de imagini biblice şi valoare didactică remarcabilă ${ }^{110}$. Ea a fost folosită în trecut pentru transmiterea învăţăturii de credinţă, dar şi-a păstrat această valoare

108 Cf. Sebastian Brock, „Syriac Liturgical Poetry - A Resource for Today”, în

The Harp. A Review of Syriac and Oriental Studies, 8-9/1995-1996, p. 54.

${ }^{109}$ Cf. Ignatius Aphram I BARsoum, Mărgăritare risipite..., p. 53-55.

${ }^{110}$ Sebastian BROCK, „Syriac Liturgical Poetry...”, p. 55. 
până în zilele noastre, având un potenţial remarcabil atât pentru educaţia religioasă, cât şi pentru instrucţia catehetică şi teologică. De exemplu, faptul că în cadrul poeziei dialogice sunt accentuate anumite momente dramatice ale relatărilor biblice, le face pe acestea să fie uşor de reţinut. Pe de altă parte, poemele narative care redau episoadele biblice într-un mod plin de viaţă, îmbogăţind textul sursă cu elemente imaginative, îl determină pe cititor să recurgă permanent la detaliile textului biblic ${ }^{111}$. Importanţa poeziei siriace pentru învăţământul teologic poate fi ilustrată prin valoarea ei exegetică. De pildă, Sfântul Efrem Sirul interpreta Biblia fie prin comentarii clasice, fie prin memrele şi madrāšele lui. Acestea din urmă sunt interesante atât pentru faptul că ele descoperă sensuri spirituale ale textului sacru, pentru care Efrem era conştient de necesitatea inspiraţiei divine,cât şi prin anumite soluţii exegetice care ne arată că el căuta uneori răspunsul la nelămuririle din textul biblic chiar în tradiţia iudaică a midraşurilor şi targumelor, atât de răspândite în zona Mesopotamiei.

$\mathrm{Nu}$ în ultimul rând, poezia siriacă este importantă şi merită studiată pentru interferenţele care au existat între ea şi imnografia creştină de limbă greacă. Cel mai cunoscut exemplu este faptul că genurile madrāša şi memrā şi-au lăsat amprenta asupra condacului, forma poetică dezvoltată de marele imnograf bizantin Roman Melodul (cca. 490-556) ${ }^{112}$. Pe de altă parte, trebuie amintit că au existat, începând cu secolul al VII-lea, traduceri de texte liturgice greceşti în limba siriacă. Unele dintre ele sunt cunoscute în siriacă cu numele ma 'nyātā, fiind răspunsuri liturgice pentru psalmi compuse în greacă de Sever al Antiohiei (†538), pe care le-a tradus în siriacă episcopul Pavel de Edessa. Ele au fost integrate în cultul Bisericii Siro-Ortodoxe (sau Siro-Iacobite), iar din secolele VIII-IX au fost amestecate cu alte cântări siriace şi adaptate sistemului melodic de opt glasuri, cunoscut din tradiţia bizantină. Tot începând cu secolul al

\section{Ibidem, p. 60-61.}

112 Cf. William L. Petersen, „The Dependence of Romanos the Melodist upon the Syriac Ephrem: Its Importance for the Origin of the Kontakion", in Vigiliae Christianae, 2/1985, p. 171-187; Alexandru PRELIPCEAN, „Sfầntul Roman Melodul - imnograful desăvârşit al Ortodoxiei”, în Studii Teologice, 2/2011, p. 59-105. 
VII-lea au mai fost traduse în siriacă poeme iambice ale Sfântului Grigorie Teologul prin osteneala lui Candidatus al Amidei, dar o mare importanţă a avut traducerea mai multor canoane greceşti. Între autorii preferaţi s-au numărat Andrei Criteanul, Ioan Damaschinul şi Cosma de Maiuma, iar traducerile au fost realizate de creştinii bizantini din Siria (melkiţii), care foloseau în cult atât limba greacă, cât şi limba siriacă. Ei au păstrat folosirea limbii siriace în cult până pe la începutul secolului al XVIII-lea, când ea a fost înlocuită definitiv cu araba. $\mathrm{O}$ parte dintre aceste canoane au fost integrate şi în cultul siro-iacobiţilor, dând naştere „,canoanelor siriace”, un nou gen în cadrul poeziei de limbă siriacă ${ }^{113}$.

Prin urmare, cunoaşterea mai aprofundată a formelor poetice siriace şi în teologia românească se dovedeşte a fi relevantă nu doar pentru îmbogăţirea culturii teologice, dar şi pentru valoarea ei catehetică evidentă şi pentru interferenţele cu imnografia bizantină. Prezenta expunere, limitată doar la perioada Antichităţii târzii şi la genurile poetice principale, se cere a fi completată cu un studiu care să reliefeze şi alte forme poetice siriace (de exemplu qanona,$' \bar{o} n \bar{i} t h \bar{a})$. În plus, merită insistat asupra colecţiilor de texte tipărite care conţin poezie siriacă (Fenqitho, Hudrā etc.), dar mai ales asupra principalelor manuscrise cunoscute, întrucât ele conţin de multe ori variantele complete ale textelor poetice abreviate în colecţiile tipărite.

$\cos 80$

\section{Bibliografie}

\section{A. Izvoare}

1. EFREM SIRUL, Imne şi alte scrieri:

ÉPHREM DE NISIBE, Hymnes contre les hérésies. Hymnes contre Julien, tome II (Sources Chrétiennes 590), texte critique du

113 Sebastian BRock, „Poetry and Hymnography (3): Syriac”, p. 666-667; IDEM, „Later Syriac Poetry”, p. 333. 
CSCO - Edmund Beck, introduction, traduction, notes et index

- Dominique Cerbelaud, Paris, Les Éditions du Cerf, 2017.

SFÂNTUL EFREM SIRIANUL, Imnele raiului, trad. Ioan I. Ică jr., Sibiu, Edit. Deisis, ${ }^{2} 2010$.

IDEM, Imnele Naşterii şi Arătării Domnului, trad. Ioan I. Ică jr., Sibiu, Edit. Deisis, ${ }^{2} 2010$.

IDEM, Imnele Păresimilor, Azimelor, Răstignirii şi Învierii, trad. Ioan I. Ică jr., Sibiu, Edit. Deisis, ${ }^{2} 2010$.

SFÂNTUl EFREM SIRUL, Imnele Perlei I-V:

„Sfântul Efrem Sirul. Imnele Perlei (I și II)”, trad. Ioniţă Apostolache, în Teologie şi viaţă, 1-4/2012, p. 224-236.

„Sfântul Efrem Sirul. Imnele Perlei (III-V)”, trad. Ioniţă Apostolache, în Teologie şi viaţă, 5-8/2013, p. 186-212.

Sfântul EFREM SIRUL, Erminii scripturistice, trad. Alexandru Prelipcean, Iaşi, Edit. Doxologia, 2018.

IDEM, Despre cea de-a doua venire a Domnului nostru Iisus Hristos, trad. Alexandru Prelipcean, Iaşi, Edit. Doxologia, 2018.

IDEM, Cuvântări de laudă la sfinţi, trad. Alexandru Prelipcean, Iaşi, Edit. Doxologia, 2019.

\section{IACOB DE SARUG, Omilii metrice:}

ALBERT, Micheline (ed.), „[Homélie VI] de Mar Jacques, contre les juifs", în Jaques de Saroug. Homélies contre les juifs, (Patrologia Orientalis 38.1), Turnhout, Brepols, 1976, p. 161-181. AMAR, Joseph P. (ed.), A Metrical Homily on Holy Mar Ephrem by Mar Jacob of Sarug, (Patrologia Orientalis 47.1), critical edition of the Syriac text, translation and introduction,Turnhout, Brepols, 1995.

3. Isaac de Antiohia, Omilii metrice:

BEDJAN, Paul (ed.), Homiliae S. Isaaci Syri Antiocheni, Paris/Leipzig, Harrassowitz, 1903.

4. *** Mireasa luminii. Imne din Bisericile Siriene despre Maica Domnului, trad. Ioniţă Apostolache şi Hermina Maria Apostolache după versiunea în limba engleză a prof. Sebastian Brock, Craiova, Edit. Mitropolia Olteniei, 2019.

5. Narsai, Omilii metrice: 
MCLEOD, Frederik G. (ed.), Narsai's Metrical Homilies on the Nativity, Epiphany, Passion, Ressurection and Ascension, (Patrologia Orientalis 40.1), critical edition of Syriac text and English translation, Turnhout, Brepols, 1979.

FrISHMAN, Judith, The Ways and Means of the Divine Economy. An Edition, Translation and Study of Six Biblical Homilies by Narsai, Leiden, Rijksuniversiteit, 1992.

6. Odele lui Solomon:

CHARlesworth, James H. (ed.), The Earliest Christian Hymnbook. The Odes of Solomon, Cambridge, James Clarke \& Co, 2009.

7. Pliny THE YOUnGer, Complete Letters, X, 96, translated with an introduction and notes by P.G. Walsh, Oxford, Oxford University Press, 2006.

8. *** Sfintele femei ale orientului sirian, texte prezentate şi traduse din limba siriacă de Sebastian P. Brock şi Susan Ashbrook-Harvey, trad. Gheorghe Fedorovici, Bucureşti, Edit. Sophia, 2005.

9. Simon Olarul, Imne:

EURINGER, Sebastian, „Die neun «Töpferlieder» des Simeon von Gêšî̀", în Oriens Christianus. Halbjahrshefte für die Kunde des christlichen Orients, neue Serie, 3/1913, p. 221-235.

10. Sogyatha mgabbyatha [Selected Dispute Poems], edited by Sebastian Brock, Glane-Holland, 1982.

11. SozomÈne, Histoire Ecclésiastique, Livre III, (Sources Chrétiennes 418), traduction par $\dagger$ André Jean Festugière, revue par Bernard Grillet, Paris, Éditions du Cerf, 1996.

12. Tertulian, Apologeticul, XXXIX:18, trad. Eliodor Constantinescu, revăzută de David Popescu, în PSB vol. 3, Bucureşti, Edit. Institutului Biblic şi de Misiune al Bisericii Ortodoxe Române, 1981.

\section{B. Dicţionare, enciclopedii şi manule}

13. AshbroOK-HARvey, Susan/Hunter, David G. (eds.), The Oxford Handbook of Early Christian Studies, Oxford, Oxford University Press, 2008: 
McGuCKIN, John A. „Poetry and Hymnography (2): The Greek World", p. 641-656.

BROcK, Sebastian, „Poetry and Hymnography (3): Syriac”, p. 657-671.

14. BROCK, Sebastian et alii (eds.), Gorgias Encyclopedic Dictionary of the Syriac Heritage, Piscataway, Gorgias Press, 2011.

15. BRANIŞTE, Ene, Liturgică generală, Galaţi, Edit. Episcopiei Dunării de Jos, ${ }^{3} 2002$.

16. MCGuckIN, John A. (ed.), The Encyclopedia of Eastern Orthodox Christianity, vol. I: A-M, Oxford, Wiley-Blackwell, 2011.

17. PAYNe-Smith, J., A Compendious Syriac Dictionary, Oxford, Clarendon Pres, 1903.

\section{Literatură secundară}

\section{Monografii}

18. APOSTOLACHE, Ioniţă, Intunericul luminos. Confluenţe şi idei mistice la Părinţii Orientali. Scrisorile lui Ioan Sabba, misticul sirian din Muntele Dalyatha, Craiova, Edit. Mitropolia Olteniei, 2019.

19. BARSOUM, Ignatius Aphram I, Mărgăritare risipite. $O$ istorie a literaturii şi ştiinţelor siriace, trad. Ovidiu Tămaş, cuvânt înainte de Terezia Filip, Baia Mare, Edit. Proema, 2016.

20. BAUM, Wilhelm/WinkLER, Dietmar W., Biserica Asiriană a Răsăritului. O scurtă introducere în istoria creştinismului sirooriental, trad. Andrei Macar, Iaşi, Doxologia, 2020.

21. Brock, Sebastian, Efrem Sirul. I: Ochiul luminos. Viziunea spirituală a lumii la Sfântul Efrem Sirul. II: Imnele despre Paradis, trad. Mircea Ielciu şi Ioan I. Ică jr., Sibiu, Edit. Deisis, 1998.

22. IDEM, From Ephrem to Romanos. Interactions between Syriac and Greek in Late Antiquity, Aldershot, Ashgate Variorum, 1999.

23.ButTs, Aaron M./HEAL, Kristian S./KITCHEN, Robert A. (eds), Narsai. Rethinking his Work and his World, Tübingen, Mohr Siebeck, 2020.

24. ButTs, Aaron M./HeAL, Kristian S./Brock, Sebastian P., Clavis to the Metrical Homilies of Narsai, (Corpus Scriptorum Christianorum Orientalium 690, Subsidia 142), Leuven, Peeters, 2021. 
25. Duval, Rubens, La littérature syriaque, Paris, Librairie Victor Lecoffre, 1900.

26. HÖLSCHER, Gustav, Syrische Verskunst, Leipzig, 1932.

27. MArtin, J.-P., De la métrique chez les Syriens, Leipzig, 1879.

28. PosseKel, Ute, Evidence of Greek Philosophical Concepts in the Writings of Ephrem the Syrian, (Corpus Scriptorum Christianorum Orientalium 580, Subsidia, 102), Leuven, Peeters, 1999.

29. PRELIPCEAN, Alexandru, „Cuvinte, dă-mi cuvinte”. De la viaţa „smeritului Roman” la teologia poetică a Melodului bizantin, Sibiu, Edit. Astra Museum, 2017.

30. Segal, Judah B., Edessa: „, The Blessed City”, Oxford, Clarendon Press, 1970.

31. TAMCKE, Martin, Creştinii din Tur Abdin. O introducere în istoria Bisericii Ortodoxe Siriace, trad. Dragoş Boicu, Sibiu, Edit. Andreiană, 2015.

32. VINTILESCU, Petre, Despre poezia imnografică din cărţile de ritual şi cântarea bisericească, Cluj Napoca, Edit. Renaşterea, ${ }^{2} 2005$.

\section{Studii şi articole}

33. APOSTOLACHE, Ioniţă, „Privire retrospectivă asupra aspectelor hristologice din teologia siriană" în Mitropolia Olteniei, 14/2012, p. 252-272.

34. IDEM, „Teologia siriană de la formare la afirmare”, în Studia Universitatis Babeş-Bolyai. Theologia Orthodoxa, 1/2014, p. 179-190.

35. IDEM, „Specificul apologetic al teologiei lui Iacob de Sarug în contextul teologiei siriene", în Revista Teologică, 4/2015, p. 53-67.

36. BROCK, Sebastian/HoPKINS, Simon, „A Verse Homily on Abraham and Sarah in Egypt. Syriac Original with Early Arabic Translation", în Le Muséon, 1-2/1992, p. 87-146.

37. Brock, Sebastian, „Dramatic Dialogue Poems”, în H.J.W. DRIJVERS et alii (eds.), IV Symposium Syriacum 1984. Literary Genres in Syriac Literature (Groningen - Oosterhesselen 10-12 September), (Orientalia Christiana Analecta 229), Roma, 1987, p. 135-147.

38. IDEM, „Syriac Dispute Poems: The Various Types”, în G.J. REININK/H.L.J. VANSTIPHOUT (eds), Dispute Poems and Dialogues in the Ancient and Mediaeval Near East. Forms and 
Types of Literary Debates in Semitic and Related Literatures, (Orientalia Lovaniensia Analecta 42), Leuven, Peeters/ Departement Oriëntalistiek, 1991, p. 109-119.

39. IDEM, „Syriac Liturgical Poetry - A Resource for Today”, în The Harp. A Review of Syriac and Oriental Studies, 8-9/1995-1996, p. 53-66.

40. IDEM, „Greek Words in Ephrem and Narasi: A Comparative Sampling”, în Aram 11-12/1999-2000, p. 439-449.

41. IDEM, „Şcolile teologice de la Antiohia, Edessa şi Nisibis”, trad. Andrei Macar, în Teologie şi viaţă, 1-4/2016, p. 149-168.

42. IDEM, „Later Syriac Poetry”, în Daniel KING (ed.), The Syriac World, Londra, Routledge, 2019, p. 327-338.

43. CASSINGENA-TRÉVEDY, François, „L'Hymnographie syriaque”, în François CASSINGENA-TRÉVEDY/Izabela JURASZ (eds.), Les liturgies syriaques, (Études Syriaques 3), Paris, Geuthner, 2006.

44. DRIJVERS, Han J.W., „Jews and Christians at Edessa” in Journal of Jewish Studies, 1/1985, p. 88-102.

45. IDEM, „Solomon as Teacher. Early Syriac Didactic Poetry”, în H.J.W. DRIJVERS et alii (eds.), IV Symposium Syriacum 1984. Literary Genres in Syriac Literature (Groningen Oosterhesselen 10-12 September), (Orientalia Christiana Analecta 229), Roma, 1987, p. 123-134.

46. IDEM, „Body and Soul: a perennial problem”, în G.J. REININK/H.L.J. VANSTIPHOUT (eds), Dispute Poems and Dialogues in the Ancient and Mediaeval Near East. Forms and Types of Literary Debates in Semitic and Related Literatures, (Orientalia Lovaniensia Analecta 42), Leuven, Peeters/ Departement Oriëntalistiek, 1991, p. 121-134.

47. IDEM, „Syrian Christianity and Judaism”, în Judith LIEU/John NORTH/Tessa RAJAK (eds.), The Jews among Pagans and Christians in the Roman Empire, Londra, Routledge, 1992, p. 124-146.

48. HalleuX, André de, „Privire critică asupra operei efremiene”, anexă în Sebastian BROCK,Efrem Sirul. I: Ochiul luminos. Viziunea spirituală a lumii la Sfântul Efrem Sirul. II: Imnele despre Paradis, trad. Mircea Ielciu şi Ioan I. Ică jr., Sibiu, Edit. Deisis, 1998, p. 261-274. 
49. KIRSCHNER, Bruno, „Alfabetische Akrosticha in der syrischen Kirchenpoesie", în Oriens Christianus. Römische Halbjahrhefte für die Kunde des christlichen Orients, 1-2/1906, p. 44-69.

50. ICĂ jr., Ioan I., „Sfântul Efrem, creştinismul siriac şi cealaltă teologie", studiu introductiv în Sebastian Brock, Efrem Sirul. I: Ochiul luminos. Viziunea spirituală a lumii la Sfântul Efrem Sirul. II: Imnele despre Paradis, trad. Mircea Ielciu şi Ioan I. Ică jr., Sibiu, Edit. Deisis, 1998, p. 5-20.

51. IDEM, „O teologie poetică a misterului pascal”, studiu introductiv în Sfântul Efrem Sirianul, Imnele Păresimilor, Azimelor, Răstignirii şi Învierii, trad. Ioan I. Ică jr., Sibiu, Edit. Deisis, ${ }^{2} 2010$, p. 5-29.

52. MACAR, Andrei, „Structuri de învățământ religios în Edessa. Şcoala perşilor", în Studii Teologice, 1/2015, p. 129-158.

53. MCVEY, Kathleen E., „Were the Earliest Madrāše Songs or Recitations?", în G.J. REININK/A.C. KLUGKIST (eds), After Bardaisan. Studies on Continuity and Change in Syriac Christianity in Honour of Professor Han J.W. Drijvers, (Orientalia Lovaniensia Analecta 89), Leuven, Peeters/ Departement Oosterse Studies, 1999, p. 185-199.

54. MÜNZ-MANOR, Ophir, „Hebrew and Syriac Liturgical Poetry. A Comparative Outlook“", în Aaron M. BUTTS/Simcha Gross (eds), Jews and Syriac Christians. Intersections across the First Millennium, (Texts and Studies in Ancient Judaism 180), Tübingen, Mohr Siebeck, 2020, p. 231-253.

55. PANAITE, Ovidiu, „Note introductive pentru o contextualizare istorică şi culturală a creştinismului syriac (II)", în Altarul Reîntregirii, 2/2014, p. 125-144.

56. PETERSEN, William L., „The Dependence of Romanos the Melodist upon the Syriac Ephrem: Its Importance for the Origin of the Kontakion", în Vigiliae Christianae, 2/1985, p. 171-187.

57. PosSEKEL, Ute, „Selbstverständnis und Bildungsauftrag der Schule von Nisibis", în Zeitschrift für Antikes Christentum, 1/2015, p. 104-136.

58. IDEM, „The Emergence of Syriac Literature to AD 400”, in Daniel KING (ed.), The Syriac World, Londra, Routledge, 2019, p. 309-326. 
59. PRELIPCEAN, Alexandru, „Sfântul Roman Melodul - imnograful desăvârşit al Ortodoxiei", în Studii Teologice, 2/2011, p. 59-105.

60. RouwhORST, Gerard, „Jewish Liturgical Traditions in Early Syriac Christianity", în Vigiliae Christianae, 1/1997, p. 72-93.

61. Russell, Paul S., „Nisibis as the background to the life of Ephrem the Syrian", în: Hugoye: Journal of Syriac Studies, 2/2005, p. 179-235.

\section{Surse web}

62. BACONSCHI, Teodor „Ucenicii lui Evagrie”, în Dilema veche, nr. $879, \quad 11-17$ februarie 2021, disponibil la adresa https://dilemaveche.ro/sectiune/din-polul-plus/articol/ucenicii-luievagrie (accesat la 14.02.2021).

63. Brock, Sebastian et alii (eds.), Gorgias Encyclopedic Dictionary of the Syriac Heritage: Electronic Edition, disponibil la adresa https://gedsh.bethmardutho.org/index.html (accesat la 04.03.2021).

64. EPHRÄM DER SYRER, Carmina Nisibena, 52:,Über den Teufel und den Tod" (Bibliothek der Kirchenväter - ediţie electronică), disponibilă la adresa https://bkv.unifr.ch/works/193/versions /214/divisions/86585 (accesat la 26.02.2021).

65. GrifFin, Carl W., Cyrillona: A Critical Study and Commentary, teză de doctorat susţinută la The Catholic University of America, Washington D.C., 2011, disponibilă la adresa https://cuislandora. wrlc.org/islandora/object/etd\%3A125 (accesată la 28.02.2021). 